OPEN ACCESS

Edited by:

Viola Liebich,

Bremen Society for Natural Sciences,

Germany

Reviewed by:

Annette Breckwoldt,

Leibniz Centre for Tropical Marine

Research (LG), Germany

Rebecca Borges,

University of Bremen, Germany

*Correspondence:

Pedro Manuel Carrasco

De La Cruz

petercarrasco27@gmail.com

Specialty section:

This article was submitted to Global Change and the Future Ocean,

a section of the journal

Frontiers in Marine Science

Received: 23 March 2021

Accepted: 16 April 2021

Published: 13 May 2021

Citation:

Carrasco De La Cruz PM (2021)

The Knowledge Status of Coastal and Marine Ecosystem Services -

Challenges, Limitations and Lessons

Learned From the Application of the

Ecosystem Services Approach

in Management.

Front. Mar. Sci. 8:684770

doi: 10.3389/fmars.2021.684770

\section{The Knowledge Status of Coastal and Marine Ecosystem Services - Challenges, Limitations and Lessons Learned From the Application of the Ecosystem Services Approach in Management}

\author{
Pedro Manuel Carrasco De La Cruz ${ }^{1,2,3 *}$ \\ ${ }^{1}$ Biodiversity Theory Group, Helmholtz Institute for Functional Marine Biodiversity, Oldenburg, Germany, ${ }^{2}$ Alfred Wegener \\ Institute for Polar and Marine Research, Bremerhaven, Germany, ${ }^{3}$ Carl von Ossietzky Universität Oldenburg, Oldenburg, \\ Germany
}

The concept of ecosystem services (ES), first introduced in 1970's, gained mainstream attention in 2005, when the Millennium Ecosystem Assessment formally proposed a definition for it. In spite of this attention, many aspects about the ES concept have remained controversial to date, i.e., their classification, value, generation, link to human well-being, and supportive role as management tool. This review explores the knowledge status of ecosystem services, focusing on those services generated in coastal and marine environments (CMES). A knowledge gap and an underdevelopment of tools to assess CMES is evident in the literature, especially when compared to the progress done in the assessment of land ES. Possible explanations reside on the yet small proportion that the research done on CMES represents for the ecosystem service framework (ESF), in part due to the intrinsic challenges of researching the marine environment, also due to the limited availability of spatial data on marine ecosystems. Nevertheless, the ES concept is getting more attention toward policy-makers and stakeholders, leading to the implementation of an ecosystem services approach (ESA) to the management and protection of CMES. Six lessons are rescued from the literature to improve the ESA: (1) integration of the ESA in a science-policy process; (2) more simplicity for the CMES prediction models; (3) move toward empowering of stakeholders; (4) integration of the value pluralism of CMES with less focus on money; (5) the link of ES to Human Well-being must not been forgotten; and (6) communication of results and social literacy are key.

Keywords: coastal and marine ecosystem services, ecosystem service approach, ecosystem services framework, human well-being, policy making 


\section{INTRODUCTION}

Since the start of the twenty first century it has become clearer to scientists and decision-makers that nature is, and will be, affected by our activities (Costanza et al., 1997; Daily, 1997; Rockström et al., 2013; Rockström, 2015; Steffen et al., 2015). The issue is then how we preserve our limited resources while obtaining what we need from the ecosystems without destroying them in the process. Perhaps no other quote embodies this urgency better than Theodore Roosevelt's quote during the Deep Waterway Convention (Roosevelt, 1907): "The conservation of natural resources is the fundamental problem. Unless we solve that problem, it will avail us little to solve all others."

Paradoxically, the importance of many ecosystems is often recognized after they are lost, as was the case of the mangrove ecosystems, following Hurricane Katrina (Chambers et al., 2007); or the Lake Erie, which was declared as dead in the 70's (Burns, 1985). At the end of the 1960's major concern arose, mainly triggered by a series of high-profile ecological disasters, including the Torrey Canyon oil spill off the coast of England (Wells, 2017), and the burning of the Cuyahoga River (Adler, 2002), inspiring the green movement and ultimately the environmental rights revolution (Boyd, 2011), calling action from governments and politicians to protect nature.

Most of the argumentation to protect nature, in the early years of this environmental revolution, was based on ethics and the intrinsic value of nature (Soulé, 1985), which generated divided attention from the public and a fierce dichotomy between intrinsic-nature supporters and instrumental users of nature (Kloor, 2015). In the last 20 years, scientists have called attention toward a shift in the paradigms of conservation (Kareiva et al., 2011; Kareiva and Marvier, 2012), and the use of holistic approaches which do not choose between nature or development, but gather the best of both (Tallis et al., 2014).

In this regard, an emergent concept has grown since 1970 when a report by The Study of Critical Environmental Problems (SCEP) entitled 'Man's Impact on The Global Environment' first introduced the term ecosystem service (SCEP, 1970). In the academic literature two publications ignited the interest on ecosystem services (ES), the book by Daily (1997) entitled "Nature's Services. Societal Dependence on Natural Ecosystems", and the article by Costanza et al. (1997) published in Nature: "The value of the world's ecosystem services and natural capital". However, it was only in 2005 that ES found a well-structured definition which mainstreamed the concept globally. The Millennium Ecosystem Assessment Report defined ES as the "benefits people obtain from ecosystems" (MEA, 2005:26).

Although the ES concept was initially criticized for namely price-tag nature, an important body of knowledge on ES has accumulated over the past twenty years, collaborating to the establishment of an ecosystem services framework (ESF). The ESF (Haines-Young and Potschin, 2010) is essentially a discursive tool which has reinvigorated the environmental agenda at the global level (Muradian, 2017), by focusing in two core topics: the classification of the ES and the evaluation of the connections that those services have to human well-being. In spite of this progress authors like Liquete et al. (2013); Patterson and Glavovic (2013);
Costanza et al. (2017); Torres and Hanley (2017) have argued that coastal and marine ecosystems services (CMES) initially received less attention from the scientific community, thus, creating a progress gap and underdevelopment of assessment tools when compared to land ES.

Marine ecosystems, whether coastal or off-shore, benthic or pelagic, are unique environments that need to be protected mostly due to three reasons: they are vitally important, not only ecologically but also economically; they are being degraded by economic activity, habitat destruction, land conversion, pollution impacts, overfishing (Barbier, 2012); and they are the focus for policy and management interventions from global to local levels (Patterson and Glavovic, 2013). Even though for long time marine science and coastal management have tended to go separate ways, generating a different set of research questions, publishing in different journals, thus, establishing separate research communities (Ostrom, 2009). Recent trends have reverted this situation, shifting toward interdisciplinary collaboration and even transdisciplinarity for the study of marine ecosystems.

In this context, a novel management tool has emerged as an alternative to incorporate the ES concept in economic decisionmaking, gathering from both the ecosystem-based management approach and the ideas of the ESF. This tool is known as the ecosystem services approach (ESA). The ESA (Martin-Ortega et al., 2015) seeks to put into a social context the worth of natural ecosystems, aiming to better manage the complex socioecological systems in which the ES are generated and delivered. However, and even though ESA has been highly recommended by a group of scientists (Daily et al., 2009; Maes et al., 2012; Costanza et al., 2017), other authors (Egoh et al., 2007; Koschke et al., 2012; Laurans et al., 2013; Stocker, 2015) agree on the inappropriate or inconsistent application of the ESA for supporting management and policy, especially when used to manage CMES.

It is impressive although, that in less than 20 years since its mainstreaming by the MEA (2005), the ES concept has expanded and dominated most of the conservation agenda (Muradian, 2017), in part due to the decline of the previous dominant paradigm, but also due to its seemingly simple message: to pay attention to the importance of human reliance on nature. Braat and de Groot (2012) have called this a new paradigm in conservation, an ecosystem services paradigm (ESP), which follows, both in academia and policy, the same basic steps: first identify ES, second assess and estimate them, and third, capture and manage values to incorporate them into decisionmaking.

In spite of the widespread dominance of the ESP, many concepts related to ES remain highly controversial, e.g., the definition of ES itself (Boyd and Banzhaf, 2007; Fisher et al., 2008; Freeman et al., 2013), the use of ecosystem valuation in the actual management of marine ecosystems (Laurans et al., 2013; Torres and Hanley, 2017), the link between the delivery of ecosystem services and the generation of human well-being (Costanza et al., 2007; Raudsepp-Hearne et al., 2010; Fisher et al., 2013), and the valuation of non-market ecosystem services, such as cultural and social ones (Fish et al., 2016; Bullock et al., 2018). The first part of this review is focused precisely on the body of literature 
addressing all those controversial issues concerning the ESP, and starting with the search of consensus for what definitions are best fit to cope with ES regarding coastal and marine ecosystems.

Although the ES concept emerged as an out-of-the-box ecological idea, mostly a reactionary view to the traditional intrinsic-conservation movements, its merit has been linked to the interdisciplinarity of its origins, especially the collaboration with economics. Hence, it is vital to elaborate on the economic perspective of ES and the implications it brings to their study and management. The second part of this review focuses on the actual management of CMES. With a fast-growing body of literature on this topic, this section will be explored from a different perspective, drawing attention over what has been recognized as key lessons (Ruckelshaus et al., 2015; Beaumont et al., 2017; Drakou et al., 2017) to generate better knowledge that can be used on the implementation of policies and the process of decision-making regarding the marine environment.

\section{WHAT IS AN ECOSYSTEM SERVICE?}

\section{The Issue of Definition}

The Millennium Ecosystem Assessment (MEA, 2005) defines ES as the benefits people obtain from ecosystems. Under this definition, ES are goods, experiences, and products derived from ecosystems. Such definition has some intrinsic issues, the one of intermediate ecosystem services, or also known as supporting services (Potschin-Young et al., 2017), and the ES as natural products without human intervention (Boyd and Banzhaf, 2007). To put into perspective, consider the case of fishing. According to the MEA (2005), captured fish is considered an ecosystem service. However, Boyd and Banzhaf (2007) pointed out that for the fish to be caught and transported to land two main inputs are needed; the presence of a harvestable fish population and, the combination of fishing time, gear quality and fishermen skills. Therefore, captured fish is neither a pure product of the aquatic ecosystem nor it should be considered an ecosystem service per se; it would rather be a benefit that we obtained from a healthy and sufficient fish population resident in the water body. The latter, under these considerations, becomes the real ecosystem service.

Mendelsohn and Olmstead (2009) summarize their standard definition as follows: "The economic benefit provided by an environmental good or service is the sum of what all members of society would be willing to pay for it." Thus, given this specific meaning, some economists argue that it is misleading to characterize all ES as 'benefits' (Boyd and Banzhaf, 2007; Fisher et al., 2008). Other economists advocate for a broader definition of ES, closer to that of the MEA (2005). For example, Polasky and Segerson (2009) argue: "We adopt a broad definition of the term ecosystem services that includes both intermediate and final services...because supporting services, in economic terms, are akin to the infrastructure that provides the necessary conditions under which inputs can be usefully combined to provide intermediate and final goods and services of value to society."
To understand this dichotomy, we can look at other often controversial examples of ES, a beach and the nutrient cycling. The first one is originally considered to provide cultural ES, i.e., joy and leisure activities to people; whereas the second is considered a regulating service, an ecosystem process necessary to maintain good water quality standards as well as a healthy aquatic food web in the sea water. Under closer inspection, however, the nutrient cycling does not provide a direct benefit to humans, it rather represents an intermediate step necessary to obtain usable clean water. Subsequently, a beach requires the combination of both ecological services, such as nutrient cycling, and human input, i.e., roads and other kind of infrastructure, which turns it into a leisure area. Therefore, we end up with two conflicting views, according to Polasky and Segerson (2009) both the beach and the nutrient cycling should be considered ES, while for Boyd and Banzhaf (2007) they should not, because one requires additional human input to provide the ES attached to it, and the other is an intermediate step necessary to have a proper and healthy beach, but which does not provide a direct benefit to people.

\section{Finding a Middle Ground}

Costanza et al. (2017) have acknowledged the prolonged debate caused by contrasting points of view about what an ecosystem service is or should be. Although it might seem trivial, it is important to remark that the problems arising from an unclear definition could subsequently built up on bigger issues such as misuse of indicators, inadequate measurement units, double counting of services during valuation, and weak incorporation of the framework and methodology into an operational decisionsupport system (Nahlik et al., 2012; Austen et al., 2019). Lack of clarity on the ES definition, also makes more difficult the communication of its relevance to the public (Saarikoski et al., 2015). Therefore, a clarification becomes necessary. In this regard, the definition provided by Fisher et al. (2008), which is largely based on the pioneer review by Boyd and Banzhaf (2007), provides a stronger ground about what ES are, "the end products of ecosystems utilized actively or passively to produce human well-being".

Under this definition, four main characteristics can be attributed to any ecosystem service (Guerry et al., 2012; Freeman et al., 2013). Firstly, they provide a benefit to people. ES are entirely linked to their contribution to human well-being, they cannot be defined independently and the benefits obtained by people could either be direct or indirect, conspicuous or unconscious, ergo their consideration as end products of nature (Braat, 2013). Secondly, ES are biophysical components of the ecosystem, but they are not ecological processes or functions. The latter can contribute to ES; however, they are not synonymous. To exemplify this, we can think about carbon sequestration in water bodies. For this ecosystem service to be achieved, it requires the conjunction of many processes and ecosystem functions to work properly, i.e., filtration of suspended matter, primary production, microbial transformation among others (Armoškaitè et al., 2020), which will remove carbon from the water to be incorporated into biomass. But these functions are not exclusive of carbon sequestration. In fact, they can also collaborate to the 
generation of other ES such as macroalgae material, wild fish, or even good water status for enjoyment of spiritual experience (Teixeira et al., 2019).

Thirdly, they can, and should, be measured as discrete units rather than as rates. To understand this we can take again the previous example. On one hand we have an ecosystem function such as primary production, which is a continuous process that changes rapidly on time. Thus, it is measured as a rate, usually of carbon, against long time periods (years), or short time periods, i.e., days (Kaiser et al., 2005; Sigman and Hain, 2012). On the other hand, carbon sequestration aims to measure fixed concentrations of carbon which are incorporated into living organisms such as macroalgae, phytoplankton biomass, seagrass, and others, whose values have low short-term variation. Lastly, they are purely natural components without any combination with human production. An example is fishing, which under this definition is mostly a benefit obtained by the combination of an ecosystem service (wild fish population of any targeted species) with common goods, such as a net, boat, fishing time (Boyd and Banzhaf, 2007).

The rationale with this definition is to make ES visible, comparable, and accountable for economic production, in a way that their value is not masked and forgotten in the process of accounting. Therefore, the focus on differentiating ES from intermediate services or ecosystem functions, as well as from the immediate analogy to benefit (SEEA, 2020), is of high relevance and demands explicit clarification when assessing ES. Nevertheless, under certain circumstances the use of the term ES could refer broadly to intermediate and final services, as long as the valuation of the ES accounts for this (U.S. Environmental Protection Agency [U.S. EPA], 2009:12-13).

This flexibility in terminology could collaborate to avoid a potentially harmful polarization within the ES user's community (Nahlik et al., 2012; Muhar et al., 2017), at the time it promotes the institutionalization of the ES concept into decision and policy systems (Steger et al., 2018). Hence, a call for a 'guided pluralism' (Hermelingmeier and Nicholas, 2017) that embraces this range of perspectives still existing around the ES definition, is suggested as possible way to address the issue as long as those perspectives involve the integration of the concept of sustainability as a guiding principle (Norgaard, 2010; Ainscough et al., 2019).

What is intended by introducing the problematic definition of ES in the beginning of this review, is to raise awareness about the ongoing and fast evolving development of the ES concept. This is a discipline with just two decades of formal scientific structuring and working (Gómez-Baggethun et al., 2010; Costanza et al., 2017), which has had as many critics (e.g., Thompson and Barton, 1994; Toman, 1998; McCauley, 2006; Simpson, 2016) as supporters (e.g., Costanza et al., 1997; Freeman, 2003; Armsworth et al., 2007; Pearce, 2007). Perhaps the words of Costanza et al. (2017) explain better what the ES concept seeks to explain: "If anything, the ecosystem services concept is a 'whole system aware' view of humans embedded in society and embedded in the rest of nature." As it was also identified by the Antwerp declaration, the major purposes of the ES concept must be to serve as an awareness raising tool, scientific approach, and decision-making aid (Ainscough et al., 2019).

\section{Defining Coastal and Marine Ecosystems Services}

According to the MEA (2003), the marine ecosystems encompass those marine areas deeper than 50 meters, while coastal ecosystems are areas located between 50 meters below mean sea level and 50 meters above the high tide level. Coastal ecosystems could extend over the continental shelf and inland up to $100 \mathrm{~km}$ from the shoreline. These categories do not represent single ecosystems. In fact, they are formed by a variety of ecosystems. However, they share a group of biological, climatic, social, and cultural factors whose consideration is useful for analyzing changes in their capacity to provide ES and the expected consequences for human well-being.

Torres and Hanley (2017) proposed a further division of the two main categories of the MEA (2003). Based on a mixed approach between management applicability and the Water Framework Directive classification of aquatic ecosystems (WFD, 2000/60/EC), they identified 8 broad ecosystem types, as shown in Table 1. The table also depicts the specific ecosystems whose services are object of valuation within each ecosystem type, and the management area each type could contribute to. Most of these ecosystem types are not mutually exclusive.

It should be stated, nonetheless, that such classification does not seek to create borders or segregation during the assessment or valuation of these ecosystems. On the contrary, it looks for an integrative approach while researching on ecosystems types which form part of a continuous seascape (Barbier, 2012; Torres and Hanley, 2017), allowing at the same time

TABLE 1 | Coastal and marine ecosystems types and management areas. Modified after Torres and Hanley (2017).

\begin{tabular}{|c|c|c|c|}
\hline \multicolumn{2}{|c|}{ Broad ecosystem types } & \multirow{2}{*}{$\begin{array}{l}\text { Specific ecosystems } \\
\text { Wetlands, mangroves, } \\
\text { marshes and swamps }\end{array}$} & \multirow{2}{*}{$\begin{array}{l}\text { Management } \\
\text { areas }\end{array}$} \\
\hline $\begin{array}{l}\text { Coastal } \\
\text { Ecosystems }\end{array}$ & Wetlands & & \\
\hline & Beaches & Beaches & $\begin{array}{l}\text { Beach } \\
\text { management }\end{array}$ \\
\hline & Coastal areas & $\begin{array}{l}\text { Coastal protected } \\
\text { natural areas, capes, } \\
\text { peninsulas and barrier } \\
\text { islands }\end{array}$ & $\begin{array}{l}\text { Coastal area } \\
\text { management }\end{array}$ \\
\hline & $\begin{array}{l}\text { Inland and } \\
\text { transitional } \\
\text { waters }\end{array}$ & $\begin{array}{l}\text { Rivers, streams, canals, } \\
\text { lakes, reservoirs, } \\
\text { deltas, estuaries and } \\
\text { catchments }\end{array}$ & $\begin{array}{l}\text { River basin } \\
\text { management }\end{array}$ \\
\hline \multirow[t]{4}{*}{$\begin{array}{l}\text { Marine } \\
\text { Ecosystems }\end{array}$} & Coastal waters & $\begin{array}{l}\text { Bays, gulfs, sounds, } \\
\text { fjords, inland seas and } \\
\text { sea waters near the } \\
\text { coast }\end{array}$ & $\begin{array}{l}\text { Coastal water } \\
\text { management }\end{array}$ \\
\hline & Coral reefs & Coastal coral reefs & $\begin{array}{l}\text { Coral reef } \\
\text { management }\end{array}$ \\
\hline & Deep sea & $\begin{array}{l}\text { Deep sea, open ocean } \\
\text { (including cold-water } \\
\text { corals) }\end{array}$ & $\begin{array}{l}\text { Deep-sea } \\
\text { waters } \\
\text { protection }\end{array}$ \\
\hline & $\begin{array}{l}\text { Marine } \\
\text { protected areas }\end{array}$ & $\begin{array}{l}\text { Marine conservation } \\
\text { zones, marine parks, } \\
\text { marine reserves, marine } \\
\text { sanctuaries and marine } \\
\text { critical habitat units }\end{array}$ & $\begin{array}{l}\text { Marine } \\
\text { protected area } \\
\text { policy design }\end{array}$ \\
\hline
\end{tabular}


to assess the trade-offs and synergies which would emerge during the decision-making process (Howe et al., 2014). In fact, key functional linkages arising from the connectivity across an entire seascape of marine habitats influence the provisioning of ecosystem goods and services (Pittman et al., 2011).

Take for example the mangrove-seagrass-coral reef seascape; all three habitats interact to provide support for marine fisheries, sediment control, and storm protection (Barbier, 2016b; Gillis et al., 2017). The connectivity among habitats mutually reinforces the support of coastal and marine fisheries because adult fish use the coastal habitats for breeding or as nurseries, with the resulting cohort migrating to coral reefs and open waters where they become part of a fishing stock. On the other hand, the sheltering effect of reefs may enhance the ability of seagrass beds, marshes, mangroves, and other coastal habitats to attenuate waves and buffer winds; whereas sediment control by mangroves and seagrass beds may also protect coral reefs, thus, enhancing their goods and services (Barbier, 2017).

\section{COASTAL AND MARINE ECOSYSTEMS SERVICES UNDER THE ESF}

If we look at the current state of the ESF, a bold but realistic statement can be drawn. Much of the work done has been preponderant for terrestrial ecosystems (Costanza, 1999; Beaumont et al., 2007; Chan and Ruckelshaus, 2010; Guerry et al., 2012; Maes et al., 2012; Patterson and Glavovic, 2013; Townsend et al., 2018). This focus is counterintuitive, considering that Costanza et al. (1997), in the first global assessment of the value of the world ecosystem services, estimated the contribution of marine ecosystems in about 63\% (US\$ 20.9 trillion/year) of the total US\$ 33 trillion/year worth in services provided by global ecosystems. An unprecedented value which, despite controversies about its accuracy (Costanza et al., 2014; Pendleton et al., 2016), has highlighted for the first time the economic importance of marine and coastal ecosystems for modern societies.

In spite of their value, coastal and marine ecosystems are among the most threatened and degraded ecosystems in the world (Martínez et al., 2007; Barbier, 2017), mainly due to their alteration as consequence of increasing human settlement in coastal areas, which has been reported to reach approximately a third of the world's human population (Small and Nicholls, 2003). A surprising fact if we consider the relatively small area that coastal zones represent for earth's land (4\% of total surface). As society's demand for coastal and marine environments increased, so did the pressure over these ecosystems caused by human activities such as fisheries, accounting for around $90 \%$ of catches only in coastal areas (Worm et al., 2009), aquaculture, shipping, recreation (MEA, 2005; Halpern et al., 2008; Diop et al., 2016; Visbeck, 2018), generating unseen levels of degradation. Moreover, global stressors, such as global warming, are expected to cause further changes and losses of mangrove forests, coral reefs, wetlands (IPCC, 2019), with the subsequent loss of those CMES delivered to society (Cooley et al., 2009; Doney et al., 2012).
Yet, the amount of data and the feasibility of methods to assess the provision of CMES are much more limited for marine ecosystems when compared to the terrestrial ones (Costanza, 1999; Barbier, 2012; Townsend et al., 2018). It is necessary to ask, why in spite of the extreme value of coastal and marine ecosystems (Martínez et al., 2007; Barbier, 2012; Barbier, 2017; Gaylard et al., 2020), their contribution to human well-being through the delivery of CMES (Costanza et al., 1997; PérezMaqueo et al., 2007; Van Der Meulen et al., 2008; O’Garra, 2009), and the acknowledgment of human increasing pressure and perturbation over marine ecosystems (Diop and Scheren, 2016), there is still a significant gap in the development of tools and methods to better evaluate CMES (Barbier et al., 2011; Patterson and Glavovic, 2013; Stocker, 2015; Lau et al., 2019).

\section{Why Did a Knowledge Gap Develop?}

A first possible reason would lead to consider that the inherent challenges of studying the marine environment have imposed certain limitations to scientists (Barbier et al., 2011; Barbier, 2012; TEEB, 2012). As consequence, CMES in general have not received enough attention. Certainly, this was true between 1997 and 2006, when an average of 2.5 papers per year on CMES were published (Liquete et al., 2013). The release of MEA (2005) brought the topic to the academic mainstream, changing for good the attention of many scientists and funding agencies toward the topic (Gómez-Baggethun et al., 2010). Liquete et al. (2013) found that the average rate of publications related to CMES increased to 23 papers published per year after 2006. However, the ES concept continues to be driven forward mainly by research on terrestrial ecosystems (TEEB, 2012; Milon and Alvarez, 2019). Apparently, within the ES scientific community, researching on CMES is a relatively new theme (Liquete et al., 2013). Costanza and Kubiszewski (2012) found a total of 2400 papers listed in the ISI Web of Science journals related to the subject of ES, but Liquete et al. (2013) detected only 279 papers specifically addressing CMES in the same searching engine. According to Townsend et al. (2018), studies on marine ecosystems represent only $9 \%$ of the ES literature accumulate over time.

Yet, united to the lack of attention, a bias focus toward certain coastal and marine ecosystems (Barbier et al., 2011) could have accentuated the delayed development of CMES assessment tools. In their review of 145 selected papers, Liquete et al. (2013) found that the most frequently analyzed study area was the coastal zone (43\%) or the coastal and marine area together (28\%). On the contrary, the open sea was the focus on around $18 \%$ of the articles. In fact, three coastal ecosystems - coral reefs, salt marshes, and mangroves - emerged as the best researched ecosystems in terms of ES assessment (Yeo, 2002; Barbier, 2007; Costanza et al., 2008; Chen et al., 2009; Davy et al., 2009; Hicks, 2011; Zhang and Smith, 2011). Other marine ecosystems, like the deep sea (Thurber et al., 2014) or the open ocean (Stocker, 2015), are recognized highly important to humanity, but hold few or none specific valuations of their ES (Jobstvogt et al., 2014; Culhane et al., 2018).

Another explanation points toward the marked differences between terrestrial and marine ecosystems in terms of their 
physical environments, ecological processes, and contemporary patterns of human impacts (Carr et al., 2003). Key characteristics of ocean ecosystems such as openness (Denny, 1993), decoupling of local off-spring (Carr et al., 2003), connectivity of the seascape (Townsend et al., 2018), and three-dimensionally of pelagic habitats (Carr et al., 2003; O’Higgins et al., 2019) have imposed restrictions to the applicability of valuation methods (Mendelsohn and Olmstead, 2009) and assessment techniques (Polasky and Segerson, 2009), originally developed to assess land ES, when applied to coastal and marine ecosystems (Maes et al., 2013; Egoh et al., 2012). Consequently, underestimation in valuation estimates (Costanza, 1999; Barbier, 2012; Costanza et al., 2014; Simpson, 2016), oversimplification of the production of services (Guerry et al., 2012; O'Higgins et al., 2019), and lack of integration of value-diversity for governance schemes (Townsend et al., 2018) are common problems when assessing CMES.

Additional complications have raised due to the scarcity of spatial data for marine ecosystems (Guerry et al., 2012; Townsend et al., 2014; Nahuelhual et al., 2020), which has limited the elaboration of CMES provision and demand maps. Although scarcity of spatial data is a usual issue in natural sciences, terrestrial ecosystems have largely benefited from the development of remote sensing technology, as opposed to marine ecosystems. With the exception of seagrass, kelp forest, and coral reefs to depth of $40 \mathrm{~m}$ (Chauvaud et al., 1998; Poursanidis et al., 2018), most coastal systems, especially benthic habitats, are unreachable for most satellites or have accuracy constrains due to high turbid coastal waters (Townsend et al., 2018). But even for those ecosystems in which maps were developed, the focus has centered on mapping single ES (Söderqvist et al., 2005; Barbier et al., 2008; Guerry et al., 2012). Liquete et al. (2013), found in their review that at least half of the articles (48\%) studied just one service, whereas only (13\%) assessed six or more services, thus, simplifying the production and delivery of CMES which most of the time are generated by different ecosystems and at different spatial scales (Raffaelli and White, 2013).

Lastly, there has been an excessive focus on local assessment of CMES (Liquete et al., 2013; Townsend et al., 2018). In their review, Liquete et al. (2013) found that $48 \%$ case studies were focused at a local scale, with only $8 \%$ reaching supranational, $4 \%$ continental, and $9 \%$ a global scale. Most of these case studies have been carried out by researchers in the global north (Costanza and Kubiszewski, 2012; Schaafsma and Turner, 2015), with the global south misrepresented or absent, as it can be noted in regions such as central and south Africa or West Asia (Figure 1). This has led to many authors underestimate the context specificity of many ES (Needham et al., 2011; Chamberlain et al., 2014; Townsend et al., 2018), and the risks of over or under valuation when applying benefit transfer between regions (Hicks, 2011; Van den Belt and Cole, 2014) or to larger scales (McGlashan and Firn, 2003; Lozoya et al., 2011). Although for some CMES, such as coastal protection or nursery ground, the assessment of highly localized patches of the ecosystem might be enough to assign proper value (Sandilyan and Kathiresan, 2012; Narayan et al., 2016), global services such as climate regulation, have a scale of assessment at the level of square kilometers, or larger, before the area becomes meaningful to service delivery (Bouillon et al., 2008; Lovelock, 2008).

\section{THE ECONOMICS BEHIND ECOSYSTEM SERVICES}

Barrett (2003), in his book 'Environment and Statecraft: The Strategy of Environmental Treaty-Making', provided information on more than three hundred international conventions which related to the environment. This much international cooperation seems to show the concern of the worldwide community with the possible collapse of ecosystems, loss of biodiversity, and increasing extinction rate of species, among other ecological issues (Pearce, 2007). At the same time, there seems to be an apparent mismatch between the people's willingness to pay for ecosystem conservation (Woodward and Wui, 2001; Horton et al., 2003), running into a magnitude of trillions of dollars, and the actual expenditures on ecosystem conservation, at best ranked at a few billions of dollars. In this regard, Pearce (2003) has argued that there is a global deficit of care to preserve both biodiversity and ecosystem services, with Deutz et al. (2020) estimating such deficit on biodiversity financing as a gap of between 598 and 824 billion US\$ per year.

But how well do expenditures for conservation efforts represent the measurement of care for the ES? If the money flowing to conservation policies is the main measurement of success, there are many pitfalls to be aware of. For example, secondary effects might be difficult to quantify after a policy measure has been set, due to amplification of the cash flow or lack of follow-up by the responsible agencies. Also, investing into one policy does not necessarily make it a good policy. Bad policies are tremendously abundant and could outweigh the effects of good ones (Pearce, 2007). Considering that research in ES has grown steadily since 2006 (Fisher et al., 2008; GómezBaggethun et al., 2010; Liquete et al., 2013; Reyers, 2013), it is surprising how little weight the ES concept has had on policy decisions (Costanza et al., 1997; Barbier, 2012; Hattam et al., 2015; Ruckelshaus et al., 2015). If ES are to be understood and effectively used, they need to be framed into a language policymakers can understand (Beaumont et al., 2007). Needless to say, ES need to be framed into economics.

Ecologists have long been reluctant to approach ecosystems and their processes with terms and methods traditionally used by economists (Beder, 2011; Baveye et al., 2013). Nonetheless, new frameworks, such as the cascade model (Haines-Young and Potschin, 2010), have received increasing recognition due to its flexibility to represent the flow of ES between the natural environment and the social, human-made world (Jacobs et al., 2016). Box 1 provides a further explanation about the model's core idea and applicability to the ESF.

An alternative, and possibly better exploration of the economic details of the ESP is offered by the ecological production theory (Boyd and Krupnick, 2013). The ecological production theory in a nutshell is the adaptation of the economic production theory to the analysis of natural systems. Under this view, ecosystems are formed by commodities that interconnect 


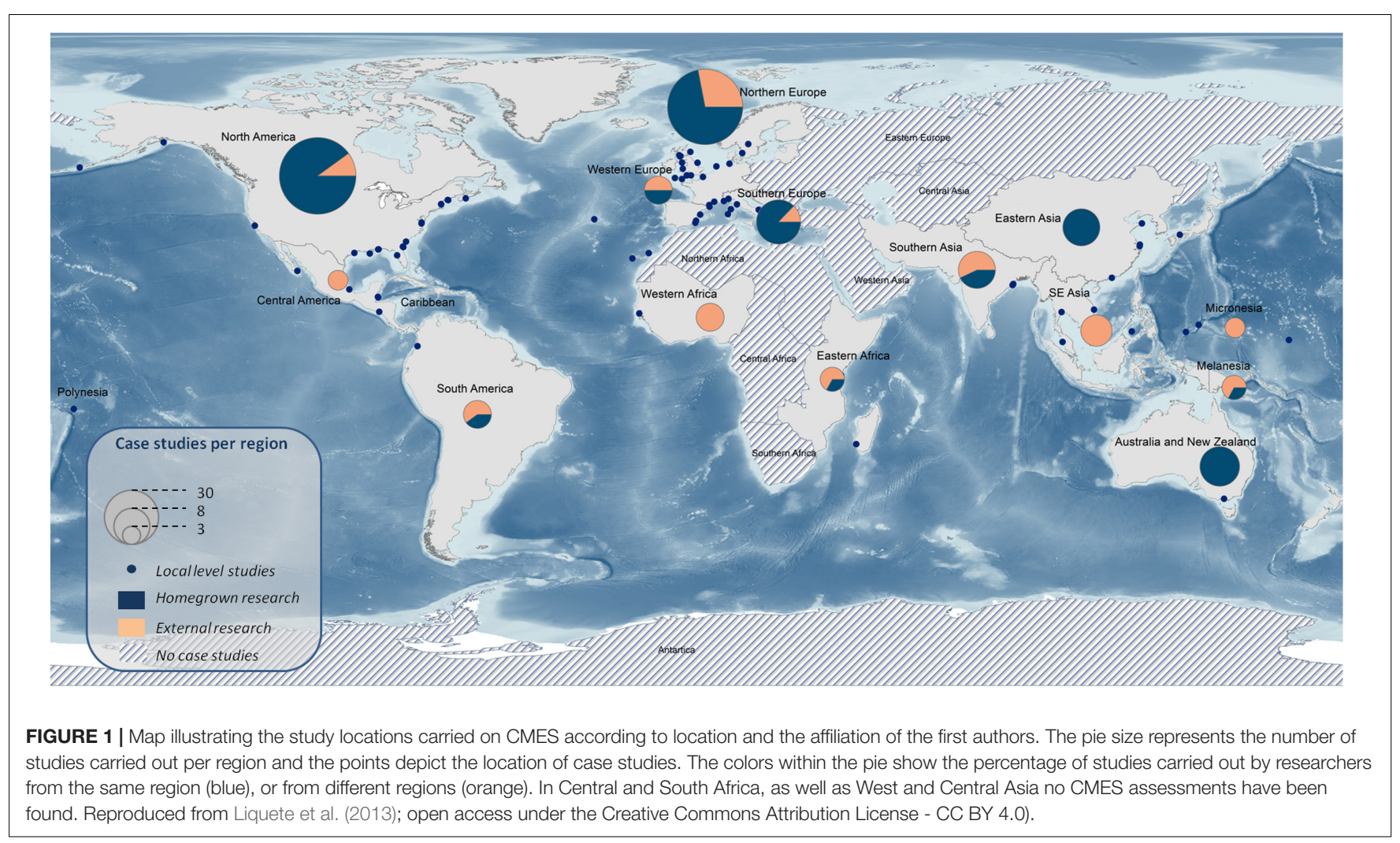

with each other through a variety of physical-chemical processes. The major challenge that Boyd and Krupnick (2013) faced by using this approach was to keep the consistency with ecological sciences, while presenting meaningful insights to their social science counterparts. A struggle which Freeman et al. (2013) conceptualized best into what they called functions. To them, functions do not strictly connect to their mathematical meaning, but rather represent a transformation, a link between the natural commodities (Boyd and Krupnick, 2013), the ecosystem services (Fisher et al., 2008), and the changes in human welfare (Haines-Young and Potschin, 2018).

\section{The Ecological Production Function (EPF)}

All the ES are the result of a bundle of processes, reactions which transfer energy between the ecosystem components, all of them occurring naturally (Austen et al., 2011). Take for example the provision of seafood. To obtain a certain amount of seafood, e.g., fish, crabs, seaweed, it was necessary to combine primary and secondary production, nutrient cycling, predation, and transfer of energy from lower levels of the food web, ultimately reaching the desire level from where the extraction, ergo seafood, was obtained. Thus, the EPF refers to all those processes that occur in nature which enable the generation of ES (Freeman et al., 2013).

In this scenario, the EPF copes with complex, invisible, and sometimes still poorly understood processes (Costanza et al., 2017) which, nonetheless, can be avoided. Understanding the variation in ES production is mostly done by monitoring ecological indicators, or bioindicators. According to Freeman et al. (2013), an indicator is a proxy for complex phenomena and can be used to reflect on the provision of a service and how it changes over time. Finding the right indicator is key for defining the EPF. Costanza and Daly (1992) and Freeman et al. (2013) have stated that a possible good way to find the right indicators is through the concept of ecosystem service providers and the ecosystem service providers efficiency (Kremen, 2005).

An example in which these concepts can be explored is by analyzing the ecosystem service of coastal erosion protection. In coastal settlements, the presence of certain habitat formations (seagrass, mangrove forest, dunes, saltmarshes) provide protection to the coastline from wave and tide action. Therefore, the extension, quality, and resilience of those structures is what we can consider an ecosystem service provider. An example frequently mentioned in literature is that of mangrove forests in tropical regions (MEA, 2005; Fisher and Turner, 2008; Liquete et al., 2013; Barbier, 2016a; Narayan et al., 2016). Here, the use of bioindicators can extend from measuring the forest area, to the average extension of the mangrove forest over critical areas, the percentage of managed areas of the forest, and the rate of deforestation and logging, among others (Valiela et al., 2001).

However, sometimes, the selection of indicators cannot be as straightforward as with this example. Many CMES are global and non-proximal (Costanza, 2008), meaning that location does not matter nor does the proximity of the location to the human beneficiaries. Likewise, many species are highly mobile, therefore, 


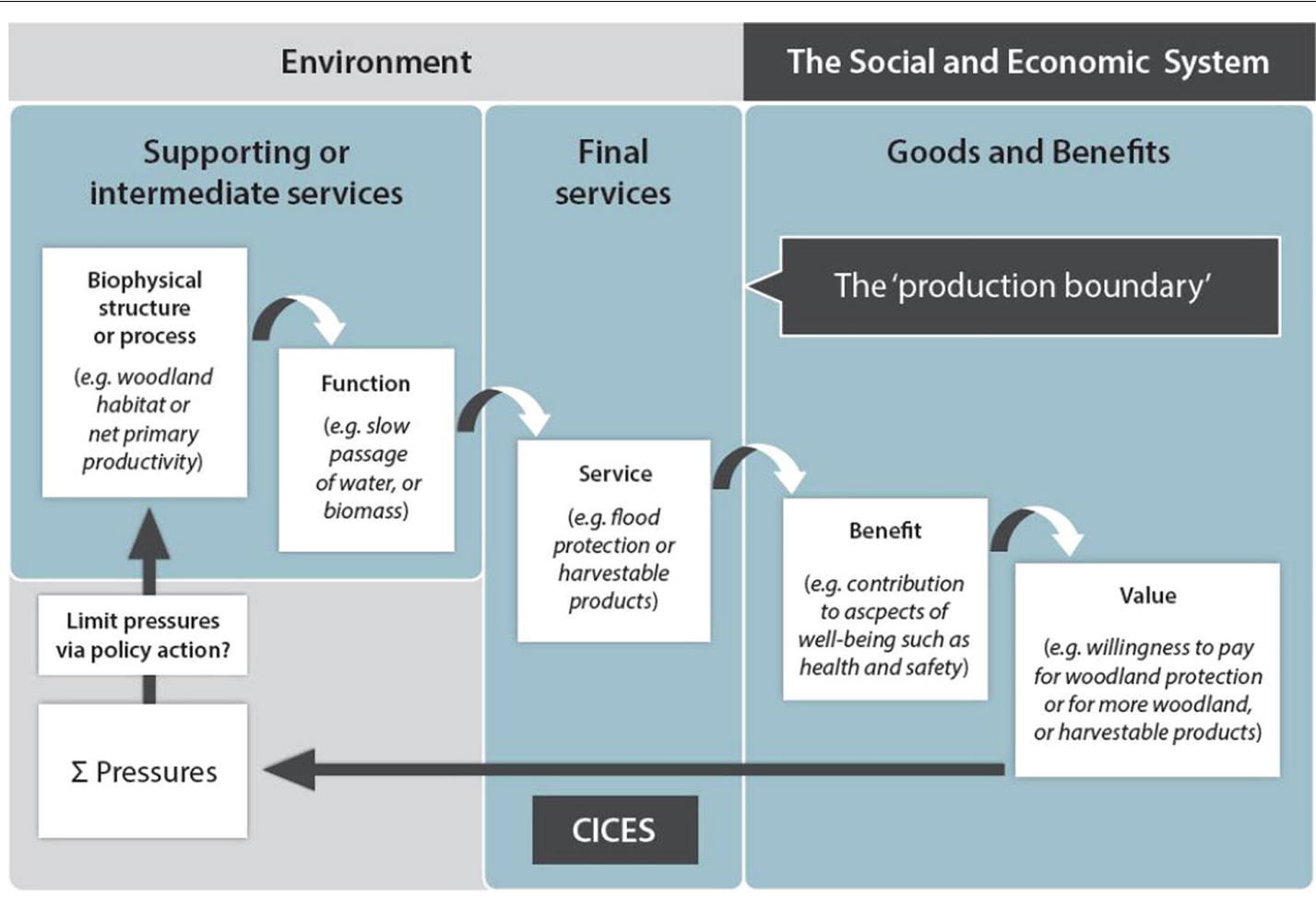

FIGURE 2 | Diagram of the ecosystem service cascade depicting the five constituents of the model. The diagram also shows the pressure of humans over the supporting services, and its possible regulation through the implementation of policy actions, e.g., via the Common International Classification of Ecosystem Services (CICES). Reproduced from Potschin and Haines-Young (2017); open access under the Creative Commons Attribution License - CC BY 4.0).

giving different relevance to various locations at different times of the year or at a particular stage in an organisms' life cycle, all affecting the provision of ES (Carr et al., 2003; Hicks, 2011). Feld et al. (2009) found that most indicators are measured at regional or local scales, with functional indicators and indicators reflecting temporal differences rarely measured, irrespective of scale. Indicators need to consider both the spatial and temporal scales at which their measurement can be effective, but such task remains yet to be done (Olander et al., 2018) and likely to be context specific (Hummel et al., 2019).

Although many researchers (Barbier et al., 2011; Hattam et al., 2015; Lillebø et al., 2016) have tried to identify a series of indicators which better work for some CMES, practical guidelines for selecting indicators are still missing (UNEPWCMC, 2011; Van Oudenhoven et al., 2012), especially for the coastal and marine environment. Nevertheless, some researchers have proposed a series of criteria which can be used to ensure the feasibility of the selection of indicators and their utility to describe the EPF. These approaches vary between three basic criteria (Link et al., 2010): measurability ("Are data available?"); sensitivity ("Can they detect change?"); and specificity ("Is the change in the indicator a response to the pressure of interest as opposed to natural variability?"). Among more exhaustive approaches, Dale and Beyeler (2001) proposed five alternative criteria, that indicators respond to stress in a predictable manner; are anticipatory (i.e., signify impending change); predict change that can be averted by management; are integrative (i.e., can indicate change over key gradients across an ecological system); and have low variability in response.

\section{The Economic Demand Function (EDF)}

The ecosystem which provides a service is usually named 'natural capital' (Costanza and Daly, 1992). This definition conveys a parallel between ecosystems and the monetary-economic capital, mainly in two points: ecosystems produce a flow of services which are attained to temporal variability and they usually interact with other kinds of capital (social, human, or built capital) to generate a benefit to human well-being (Costanza et al., 2017). The connection between ES and the benefit we humans obtained from them represents the economic demand function (EDF). In simple words, it is the realized enjoyment of an ecosystem service (Hattam et al., 2015).

This human enjoyment placed into economic terms means welfare. A common mistake here is to assume that human welfare is referred exclusively to monetary welfare, like dollars in a bank account. Money is certainly the most common metrics to measure welfare, but welfare can rather be approached as a wide range of metrics when using the EDF, such as satisfaction, number of people benefited, among others. Contrary to the EPF, the processes which generate an EDF are often discernible, closer to society, but perhaps not less challenging to represent. The challenge resides now in how to best represent the variation of human welfare according to the ES dynamics. 
BOX 1 | Understanding the Cascade Model.

In 2010, Haines-Young and Potschin proposed an idea which would summarize much of the logic underlying the ESP. By this time, research on ES had already increased exponentially (Potschin and Haines-Young, 2011). It started to be clear that there was some sort of production chain linking ecological and biophysical structures and processes on one hand, with elements of human well-being on the other. However, the ideas of Boyd and Banzhaf (2007) and Fisher et al. (2009) were fundamental to make ends meet in what could be considered an ecosystem service. Two of these ideas were also essential for the elaboration of the cascade model. First, a service is only a service if a human beneficiary can be identified; second, it is important to distinguish between the final services that contribute to people's well-being and the intermediate ecosystem structures and functions that give rise to them.

The cascade model is formed by five elements, shown in Figure 2, which are constituents within the natural system (environment) and the social and economic system. In the natural system, supporting or intermediate services which are formed by biophysical structures or processes and functions - give rise to the final service, whereas this final ecosystem service provides a good and/or benefit to humans, which is ultimately valued according to context, culture, or economic reasons (TEEB, 2010, 2012; Box 2 for further explanations about the meaning of value in ES). This model suggests a tight relationship between people and nature embodied in the ES concept. It argues the need to identify both the functional characteristics of ecosystems that give rise to services, and the benefits and values that they support (Potschin and Haines-Young, 2011, 2016) to fully grasp their production-delivery relationship.

However, some authors have disagreed with the idea of a cascade for the ES concept arguing that it is an oversimplification of a complex reality (Costanza et al., 2017); it generates confusion on what a function in relation to ES is (Balmford et al., 2011), or on the distinction between service itself and benefits (Bateman et al., 2011; Mace et al., 2011); and that its final outcome or motivation is the valuation of ES (Naber et al., 2008). Other authors have proposed modifications to the number of main elements of the model, or have even proposed a new version of it (Villamagna et al., 2013). For example, Costanza et al. (2017), elaborated their own framework that considers ES equal to benefits, proposing higher complexity and a dynamic, instead of a linear relationship between nature and the social system.

Nevertheless, many publications (Potschin and Haines-Young, 2011, 2016; Potschin-Young et al., 2017) have expressed that the intention with the cascade idea is to highlight the essential elements that have to be considered in any ecosystem service assessment, and the kinds of relationships that exist between them. The assertion is that no individual component should be looked at in isolation, but rather from an inter- and even transdisciplinary perspective.

In this regard, it is necessary to argue about the convenience of using the cascade as a model (Rounsevell et al., 2010), or rather as a flexible conceptual framework (Potschin-Young et al., 2017). The Intergovernmental Platform of Biodiversity and Ecosystem Services - IPBES - (UNEP, 2014; Díaz et al., 2015) has highlighted the advantages of frameworks as tools which simplify thinking, structure work, clarify issues, and provide a common reference point. Moreover, the EU-funded OpenNESS Project found that the cascade model has been used as an organizing framework (Pagella and Sinclair, 2014; Tolvanen et al., 2016), a tool for reframing perspectives (Spangenberg et al., 2014a,b; Brink et al., 2016), an analytical template (Boulton et al., 2016; Guisado-Pintado et al., 2016), and as an application framework (Chapman, 2014; Daw et al., 2016;

Gissi et al., 2016).

In spite of controversies or preferences, the cascade model has helped answer important questions about the ESF, including whether there are critical levels of natural capital needed to sustain the flow of ecosystem services, if capital can be restored once damaged, what the limits to the supply of ecosystem services are in different situations, and how we value the contributions that ES make to human well-being

(Potschin and Haines-Young, 2011).
BOX 2 | The Meaning of "value" for the ESF.

Value is, in its broader meaning, "an estimation of the worth of something" (Stevenson, 2010). But the word value can also refer to a principle associated with a given worldview or cultural context, a preference someone has for a particular state of the world, the importance of something for itself or for others, or simply a measure (Pascual et al., 2017). All these different meanings of value are linked through the process of valuation. In the ESA, the process of valuation is not more than to assign importance, or generate preferences for certain behaviors, that allow to measure ES's values by means of an adequate tool and to express them in informative metrics (Pascual et al., 2017; Arias-Arévalo et al., 2018). For example, think about the amount of fish produced per square meter on a tropical reef (metric). This represents just a proxy to express the importance (value) of the coral ecosystem from an economic point of view. However, from an ecological point of view, we can measure the value of the coral reef based on the diversity of species it holds, its spatial extension, or its health status (Farber et al., 2002). All these estimations involve a process of valuation, always performed by us humans (Farley, 2012), as both individuals and society, ultimately having an impact over our well-being. Therefore, a properly structured and transparent assessment of ES values is necessary to guide and balance the relevance given to those ES. However, the valuation of those benefits we obtained from ES is complex and subjective (Small et al., 2017).

According to The Economics of Ecosystem and Biodiversity (TEEB, 2010, 2012), benefits and values can be better understood when separated in three categories: (1) ecological, (2) socio-cultural, and (3) economic ones. De Groot et al. (2010b) found this distinction necessary due to the multiple levels at which benefits from ecosystems satisfy the needs of different groups of people, hence, the subjective value they acquire. They used the example of fishermen and their income in different cultures to elaborate in this idea. Artisanal fishing is not as profitable now as it used to be decades ago (Belhabib et al., 2016; Barange et al., 2018); however, for some cultures, it still represents a source of identity, a bond with nature. For the new generation of fishermen, the value of fishing could reside more in the social aspect rather than in the economic profit (Chan et al., 2016).

The first category, ecological values are crucial for human survival since they play key roles in the maintenance of essential life-support processes (MEA, 2005). Among them we find functional integrity, health, and resilience of an ecosystem to sustain life (De Groot et al., 2010b). These are critical values for keeping the provision of ES (TEEB, 2010) and to guarantee the sustainability of ecosystems (Wood et al., 2018). Brondizio et al. (2010) described the second category, socio-cultural values, as culturally shaped and derivate from three value domains: 'intrinsic value,' which is the value of an ecosystem on its own, regardless of what people could obtain from it (O'Neill, 2002); 'instrumental value', the contribution to the beneficiary's wellbeing (Kenter et al., 2015); and lastly, 'relational values', meaning the concerns associated with relationships and responsibilities between people or between nature and people (Chan et al., 2016). Economic values, the third category, express the importance of ES in monetary terms. This monetary value encompasses both, use value (direct or indirect) and non-use value. The accuracy with which these economic values can be measured varies and it seems to be method-dependent (De Groot et al., 2010a).

The IPBES has also developed a conceptual framework which identifies three inclusive elements in the interaction between human societies and the non-human world, among others: (1) nature; (2) nature's benefits to people; and (3) a good quality of life (Díaz et al., 2015). IPBES assumes a value pluralism perspective by acknowledging the diversity of worldviews and values, thus, leading stakeholders to a different iterative approach regarding the identification of policy objectives and instruments. The IPBES approach emphasizes that values are fluid and sometimes cannot be placed rigidly into one category (e.g., instrumental or relational), illustrated by the color gradient of Figure 4. As Arias-Arévalo et al. $(2017,2018)$ concluded, the narrative is an important element which is sometimes overlooked when approaching the valuation process and usually supports the following three value typologies: living for nature (intrinsic in the sense of the direct moral consideration of non-human subjects of a life), gaining from nature (instrumental), and living in nature (relational). 


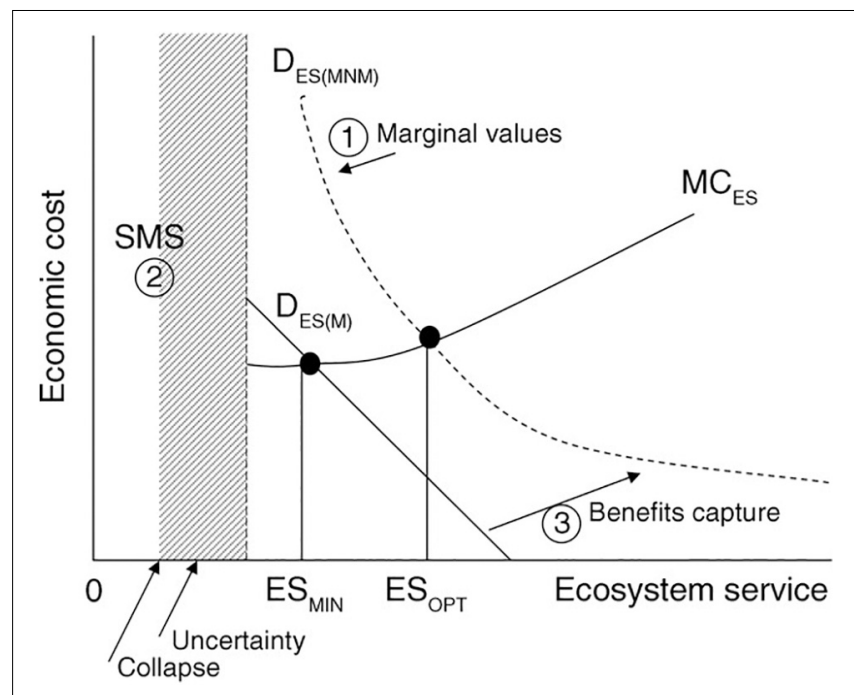

FIGURE 3 | The graphic representation of the economic demand function (EDF). The $D_{E S(M)}$ curve represents the variation of ES traditionally traded in markets, thus, with use value, whereas the $\mathrm{D}_{\mathrm{ES}(\mathrm{MNM})}$ curve represents all those services which hold a non-use value. At some level of degradation, both curves behave differently, but both run into a problem of uncertainty and possible collapse. Reproduced from Fisher et al. (2008).

In this regard, authors like Boyd and Banzhaf (2007); Pearce (2007); Fisher et al. (2008); or Boyd and Krupnick (2013) have offered perspectives about how to represent this dynamic. In the simplest way, an EDF can be visualized as a typical demandsupply curve (Pearce, 2007). Imagine we have a two-axis plot, in which the $\mathrm{x}$-axis represents the ES supply level, while the $y$-axis represents the valuation level given by humans. Thus, as it happens in economics, the variation in the $y$-axis is bounded to the valuation given by humans if obtaining an extra unit of the ES represented in $x$-axis. The key word to understand here is value (in Box 2 an explanation is given about the complexity and subjectivity this word has for the ESP); therefore, for the EDF only the economic values hold a relevance, whether those are use values (direct and indirect) or non-use values.

In Figure 3, a conceptual analysis based on Pearce (2007) and Fisher et al. (2008) is explored. These authors recognized both the different EDF curves when assessing use-value (marketed ES) and non-use values (non-marketed ES). ES associated with markets in which formal exchange takes places have a negative slope curve $\left[\mathrm{D}_{E S(M)}\right]$. High provision of an ES is valued less since there is not major lack or unsatisfied demand, whereas as the ES becomes scarce, moving left in the $\mathrm{x}$-axis, the valuation cost steeps up in the $y$-axis. We can easily imagine this scenario when thinking about fish, fuel, food, wood which are sold in a market with price tags attached.

On the other hand, ES which have been for long considered abundant or impossible to trade in conventional markets skip the first curve. Therefore, a second curve which merge both marketed and non-marketed ES $\left[\mathrm{D}_{E S(M N M)}\right]$ is established. Although this curve presents a downward trend too, it bends sharply when the provision of ES is low. Moreover, the $\mathrm{D}_{E S(M N M)}$ curve lies somewhere above the $\mathrm{D}_{E S(M)}$ (Pearce, 2007). Farley (2012) argues that the reasons for the differences between the $\mathrm{D}_{E S(M)}$ and the $\mathrm{D}_{E S(M N M)}$ are the apparent abundance of non-marketed ES in human history, which led them to be outside of economic analysis and ultimately to become externalities in production chains; as well as the impact that a shortcut provision, meaning a sharp and sudden scarcity of ES, would have over the willingness to pay of humans.

As for the supply of ES, a positive rising curve is defined. This curve could be understood as the supply curve of the EDF, but is called here the marginal cost of ES $\left(\mathrm{MC}_{E S}\right)$. Pearce (2007) understood this curve as comprised by the cost of managing ES, or, in other words, of conserving them, plus the opportunity cost, i.e., the cost forgone due to conserving a given ecosystem service instead of using it now. The $\mathrm{MC}_{E S}$ fulfills the expectation of the increasing cost which brings the provision of more ecosystem service (Small et al., 2017).

\section{Implications of an Economic Framework for CMES}

In Figure 3, there are three details that need further consideration. Firstly, the interception of $\mathrm{D}_{E S(M N M)}$ and $\mathrm{D}_{E S(M)}$, with the $\mathrm{MC}_{E S}$ originates two points known as $\mathrm{ES}_{M I N}$ and $\mathrm{ES}_{O P T}$. While the $\mathrm{ES}_{M I N}$ depicts the point where only marketed services are provided, the $\mathrm{ES}_{O P T}$ considers also those services which are not traded in markets. Although it might seem complicated at first, the idea is very insightful. Consider the case of fisheries stock assessment. As we saw previously, the ecosystem service provided here would be limited to the part of the fish population with the preferred size at the right time of the year. However, if what is solely considered in the determination of the fish stock is the fish needed to satisfy human demands, fish as food (i.e., $\mathrm{ES}_{M I N}$ ), we are overlooking the role that same fish is playing as part of the ecosystem either as food for other species, as a key species in the ecosystem or as intermediate link in the production of another ES $\left(\mathrm{ES}_{O P T}\right)$. Therefore, the risk of considering only the $\mathrm{D}_{E S(M)}$ is to generate an under-provision of ES, when $\mathrm{ES}_{M I N}<\mathrm{ES}_{O P T}$ (Fisher et al., 2008).

Secondly, ecologists have predicted that perturbations in the functioning of ecosystems would limit their capacity to provision services (Chapin et al., 2000; Loreau et al., 2001; Villamagna et al., 2013; Villasante et al., 2016). Hence, it is necessary to consider a safe minimum level in which the ecosystem's components (including biodiversity, populations, and interactions) are enough to maintain the functions that give rise to the various CMES. This level is represented in Figure 3 as the Safe Minimum Standard (SMS). The issue relies on where exactly this line should be drawn, as the uncertainty is currently great due to the nature of each ES and the state of the ecosystem under assessment (Dobson et al., 2006).

Thirdly, in spite the validity of $\mathrm{D}_{E S(M N M)}$ to capture the real benefits of ES provision, its application is limited under current context because our inability to capture the value of non-marketed ES (Fisher et al., 2008). In other words, in strictly economic terms, those services which are not traded in markets or lack at all of one, cannot be attribute a monetary value 


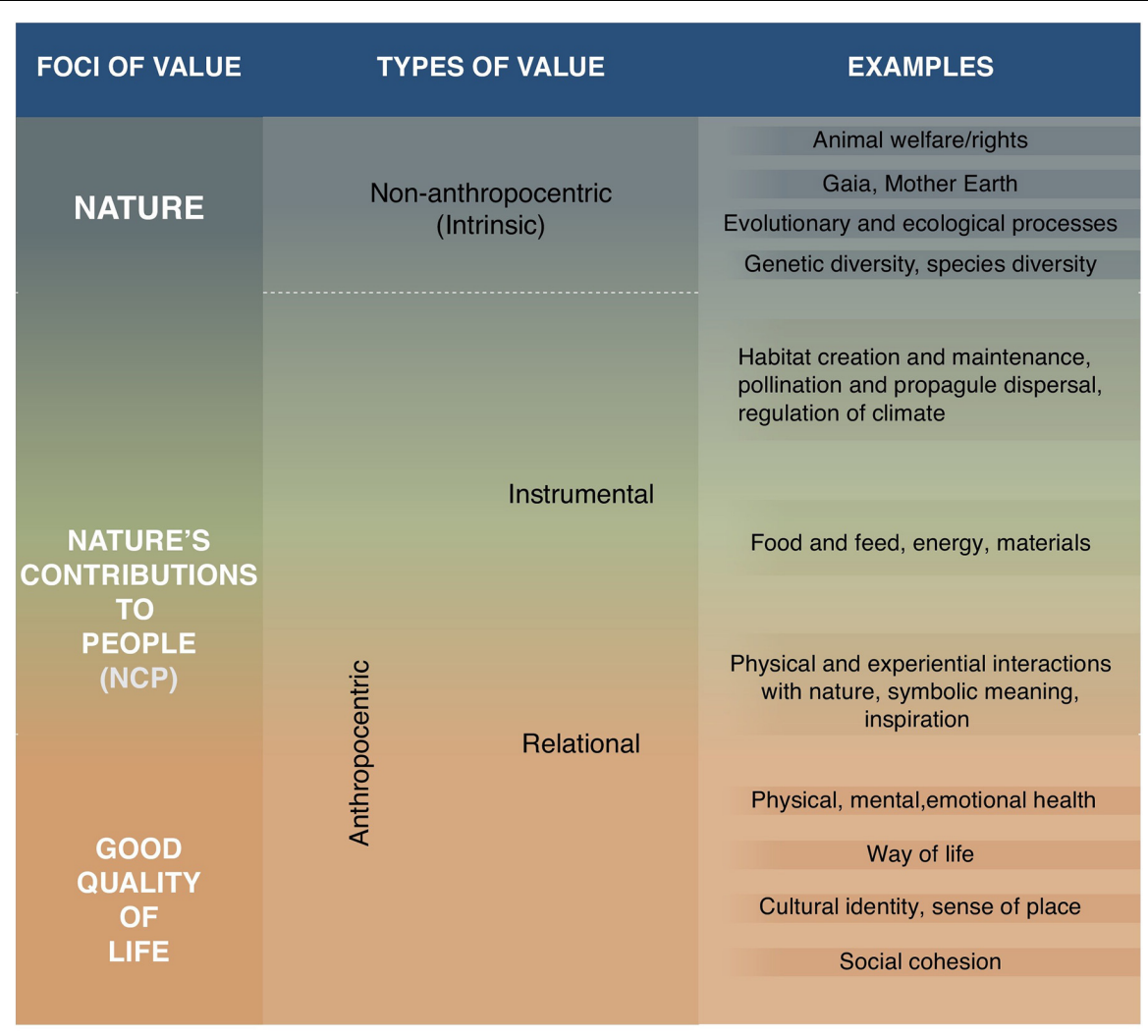

Current Opinion in Environmental Sustainability

FIGURE 4 | Diverse values related to nature, nature's contributions to people and a good quality of life. The grading in the colors indicates that both instrumental and relational values can be ascribed to the value of nature's contributions to people, and to highlight that it is intertwined with nature and a good quality of life.

Reproduced from Pascual et al. (2017); open access under the Creative Commons Attribution-Non-commercial-No Derivatives License - CC BY-NC-ND 4.0).

(Freeman et al., 2013; Small et al., 2017). This scenario will progressively contribute to the undermining of ecosystems and induce limitation of policy-makers to conserve them (Sagebiel et al., 2016). Pearce (2007) proposed the creation of a dual process of economic valuation by capturing those values under some sort of market creation, whilst Fisher et al. (2008) proposed keeping distance from monetary valuation, since it is not necessary but always generates issues due to its imprecision and difficulty (Kahneman et al., 1993; Bateman et al., 1997a,b). What turns out relevant from the application of this framework is that capturing the benefits of those non-marketed ES is essential for a meaningful future of the ESP (Schuhmann and Mahon, 2014).

\section{THE MANAGEMENT OF CMES}

In 2008, the Ecosystem Service Partnership $\left(\mathrm{ESP}^{1}\right)$, an international community of more than 3000 scientists, policymakers, practitioners, stakeholders, and end-users of ecosystem services, started a series of annual conferences aiming to gather its members to work on identifying the

\footnotetext{
${ }^{1}$ The ESP provides many tools to further enhance the application of ES for nature conservation, ecosystem restoration and sustainable management. More information available at https://www.es-partnership.org/.
}

accomplishments and gaps of the ES concept to date. Under the title of "Solutions for Sustaining Natural Capital and Ecosystem Services," the conference of 2010 produced a major message for the world, which is known as the Salzau Message.

Burkhard et al. (2012) reproduced a fragment of this message: "The human population of earth is likely to increase to 9 billion people by the end of the century, the global climate is being transformed, biodiversity loss continues, and conventional, fossilbased economies are no longer a viable option. Business as usual is a utopian fantasy. If we are to improve the sustainable well-being of humanity [...] a precautionary approach to decision-making should [...] be adopted. We believe that solutions to providing a sustainable and desirable future require broad recognition of the basic facts about ecosystem services and natural capital, and advances in two key areas: (1) integrated measurement, modeling, valuation and decision science and; (2) adaptive management and new institutions."

The MEA (2005) made evident that human use of ES is expanding, at the same time that the status of most of those services show a decreasing trend (Figure 5). Alarming is the decline in regulating services, whose deterioration foreshadows future declines in other ES. Indicators show that future trajectory will continue to be unfavorable unless society acts to combat the adverse trends (Leslie and McLeod, 2007; Carpenter et al., 2009). 
Like the MEA in 2005, the "Salzau Message" acknowledged the inevitability of change in the status quo if we want to achieve sustainability, and proposes the ES concept as a tool to guide the process of decision-making and the management of the Natural Capital. This strategic integration of the ES concept into the ecosystem approach (CBD, 2000) is known as the ESA.

The ESA is, in short, a strategy which acknowledges the complexity of human-nature interactions and the need for interdisciplinarity to manage the complex social-ecological systems in which ES are generated, delivered, and ultimately enjoyed by humans (Ostrom, 2009). The ESA could take various forms and include numerous methods, but according to Martin-Ortega et al. (2015), it is based on four common aspects: it requires a valuation of ES based on the benefits humans get from them; ES are the product of ecosystem processes, a relationship which should be explicitly described; interdisciplinary collaboration together with stakeholder engagement at various levels is required; and the outcomes are susceptible to be incorporated into environmental policy and management decision making.

The ESA has been increasingly recommended to inform environmental management and planning (Daily et al., 2009; Maes et al., 2012; Börger et al., 2014), and efforts to apply it at different governmental scales are notably more apparent (Beaumont et al., 2017), being the establishment of the Intergovernmental Science-Policy Platform on Biodiversity and Ecosystem Services $\left(\right.$ IPBES $^{2}$ ) in 2012, a major milestone in the pursuing of this effort. However, many authors agree on the inappropriate or inconsistent application of the ESA for supporting management and policy-making of CMES, with reasons including its overwhelming complexity (Koschke et al., 2012; Collie et al., 2013), the relatively poor number of success stories of CMES assessments included in decision making (Laurans et al., 2013), to the lack of clear guidelines about which of the many possible CMES could and should be quantified (Egoh et al., 2007), or other issues related to governance systems (Olsen et al., 1997).

Daily et al. (2009) argued that for the ESA to gain more weight in the decision-making process, two fundamental changes need to occur. First, the science of ES needs to advance rapidly; second, the ESA must be explicitly and systematically integrated into decision making by individuals, corporations, and governments. The first change is already happening (Boyd and Banzhaf, 2007; Fisher et al., 2009; De Groot et al., 2010a; Potschin and HainesYoung, 2011; Barbier, 2012). Definitions, metrics, frameworks of assessment, and future directions of the field are clearer now than in 2009. In spite of this growing body of literature and interest on ES, the effective application of the ESA for coastal and marine ecosystem management and its integration into the planning, management, and design of policies is still at an early stage (Boulton et al., 2016; Rivero and Villasante, 2016; Robinne et al., 2018).

${ }^{2}$ IPBES is an "independent intergovernmental body," with secretariat office located in Bonn, Germany. It was created with the objective of enabling and improving the international use of the ESA in policymaking, primarily by providing an interface between the scientific community and policymakers. Website: https://www.ipbes. net/.
Despite the incipient state of the ESA, the fact is that its application has had valuable lessons to build upon (Richardson et al., 2015; Beaumont et al., 2017; Steger et al., 2018). However, the management of CMES is not a typical 'forward problem' that could be solved by following a set of predetermined steps; it could rather be considered an 'inverse problem'. An inverse problem consists in using the results, or observations, to infer the values of parameters characterizing the investigated system (Tarantola, 2006). Translating this concept to the ESA means using the literature available, the success and failure stories, to find the weaknesses of the system that would allow to improve the same system used during the application of the ESA (Tarantola, 2006). Following Tarantola (2005), we need to ask ourselves how does the newly acquired data modify our previous information? What is proposed in the following section does neither intend to focus on single case studies nor to review in detail each single framework proposed by a particular author. Instead, I propose a "review of reviews".

What the contribution at hand calls a review of reviews is simply to focus on the documentation of lessons learned when the ESA was applied in a real decision-making context. These reviews are not abundant (Ruckelshaus et al., 2015; Beaumont et al., 2017; Drakou et al., 2017). However, they are extremely valuable in terms of giving an insightful perspective on the application of the ESA, since, in most of the cases, the authors did not just compile a group of case studies, but rather participated totally or partially in the implementation, execution, and posterior analysis of results of those cases. By focusing on the lessons learned, we can turn back to the ESA system model and take a look at what needs to be improved for future applications, considering the particularities of the given contexts.

\section{Moving From Knowledge to Real-World Decision Making}

Based on the review of the work of Ruckelshaus et al. (2015); Beaumont et al. (2017), and Drakou et al. (2017), six key lessons were identified. These lessons are recognized as milestones for improving the ESA's application. They aim to increase the potential use of the ESA for the management of CMES and the generation of greater impact (Posner et al., 2016) on management schemes at different governance levels and over a wide variety of countries (Sattler et al., 2018). Although the three reviews did not base their findings on the same case studies, or even came to the same conclusions, they mostly focused on similar key points of the ESA process. Therefore, it is precautionary for the reader to be aware of the limitations of this review, which, except for Ruckelshaus et al. (2015), had their case studies located mostly in the global north. Therefore, contextualizing is extremely relevant if replication in other realities is intended (Pendleton et al., 2015).

\section{Lesson 1 - Impacts Are Greater When the ESA Is Part of a Science-Policy Process}

Ruckelshaus et al. (2015) asked this key question during their research: "What kind of information is needed to create useful, credible science and change decision process and outcomes?". They found it is hard to know unless an interactive transdisciplinary science-policy process is implemented, in which 


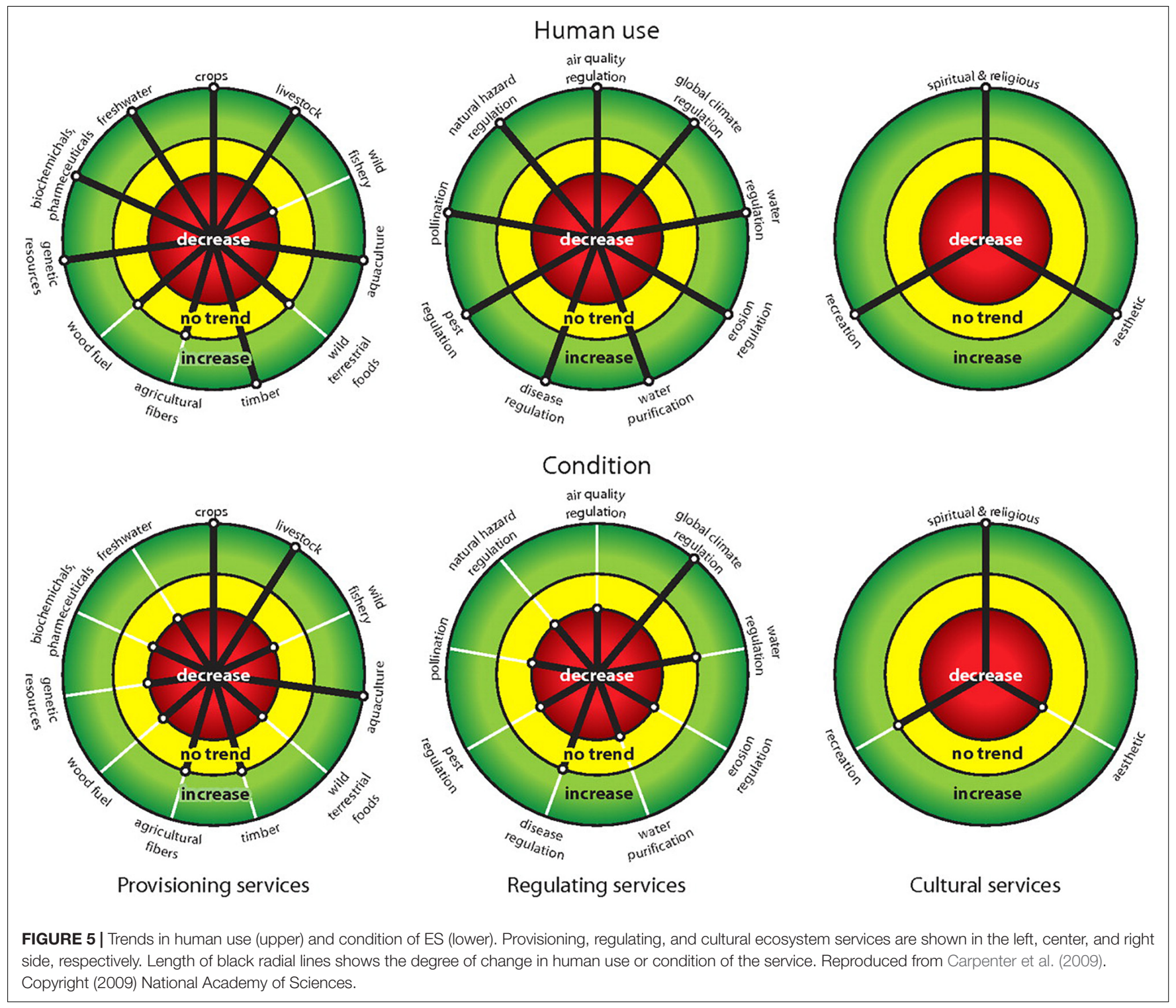

scientists, local experts, stakeholders, and decision makers are involved. In other words, for CMES to be operatively used to inform decision-making, science cannot be a simple provider of information, but rather a process of knowledge integration should take place (Posner et al., 2016; Drakou et al., 2017). Likewise, the ESA should help to clarify which CMES are susceptible to be quantified, with what tools, and ultimately if the application of the ESA would help clarify a particular policy decision (Pendleton et al., 2015; Steger et al., 2018).

The process to accomplish this integration is, as expected, highly complex and time consuming (Bagstad et al., 2013). However, in places like Belize, it certainly has created a significant impact (Arkema et al., 2015). In 2010, Belize’s Coastal Zone Management Authority and Institute (CZMAI) started a collaboration with The Natural Capital Project (NatCap) ${ }^{3}$ and

${ }^{3}$ The Natural Capital Project (NatCap) was formed in 2006 with the primary goal of transforming decisions affecting the environment and human well-being
World Wild Fund for Nature (WWF) to create a national coastal zone management plan. This collaboration brought interesting synergies to both sides, allowing NatCap to gather critical local knowledge that was later used to co-develop alternative zoning schemes, producing scenarios that were relevant to local stakeholders and provided just the necessary level of input detail to the Integrated Valuation of Ecosystem Services and Tradeoffs (InVEST) models for exploration of likely CMES outcomes (Coastal Zone Management Authority Institute [CZMAI], 2012).

However, once the importance of this integration is acknowledged, how should it be framed? Daily et al. (2009) proposed a framework in which the ESA is outlined into a linear sequence formed by five stages: Institutions, Decisions, Ecosystems, Services, and Values. Each stage is linked to a process which involves the flow of information in the form of models,

by providing clear and credible ES information for decision makers. More information available at: https://naturalcapitalproject.stanford.edu/. 
valuation or incentives. This framework resembles the cascade model (Haines-Young and Potschin, 2010) with the addition of the governance level affecting all the other stages.

Lopes and Videira (2013) proposed an iterative process which breaks down the process into three main stages. Firstly "Set the scene", which involves a listing of all the institutions that could potentially affect the decision, including the identification of relevant stakeholders. Secondly, "Deepen understanding", involving three steps: (1) identification of ES and their variation; (2) identification of long-term impacts on ES; and (3) the social, ecological, and economic values attributed to the different affected services. Lastly, "Articulate values," meaning to reach the aggregation and weighting of the different values assigned to ES and their effect in the decision-making process. This framework aims to produce information on the values of ES based on the different visions and perspectives of multiple stakeholder groups. Moreover, it promotes social learning for stakeholders and the institutions in charge of the decision-making process.

A downside of this iterative science-policy process is that it is time consuming (Ruckelshaus et al., 2015; Hummel et al., 2019). Hence, it is critical to align the scope of activities with the objective pursued by the stakeholders, so that a greater impact is generated (López-Rodríguez et al., 2019). In this sense, we must understand that impact could be diverse because it varies according to the context in which the ESA is applied. Kingdon (1995) argued that the time span for new information to influence real decision could vary from months to even decades. Therefore, success should be measured at several points along the decision making-process (Beaumont et al., 2017). Ruckelshaus et al. (2015):(12) talked about a 'diversity of successes', meaning that there are different pathways constituting some form of success in incorporating ES information into decisions and outcomes. For explanation, they developed a framework of four pathways (Figure 6), in which deeper impact is achieved when the process evolves from top to bottom down each pathway, and from left to right between the four pathways (Ruckelshaus et al., 2015). Science-policy engagement will traverse these pathways to a different extent, and the stages can be used to track progress which is not always linear.

\section{Lesson 2 - Simplicity Is Mostly Preferred Over Complexity}

The use of modeling tools for the ESA has a strong component of subjectivity (Daily et al., 2009; Ruckelshaus et al., 2015; Costanza et al., 2017). This means that models, usually developed solely by scientists, are perceived as complex and difficult to use by decision-makers and other stakeholders (Guerry et al., 2012). The models created by scientists are seen from their perspective as simplified versions of biophysical and socioeconomic processes. In spite of that, decision-makers tend to ask for simpler, fit-to-objective, and more understandable tools which can be incorporated into the science-policy processes (Ruckelshaus et al., 2015; Wam et al., 2016). Decision-makers are often best served by relatively simple models, as long as they

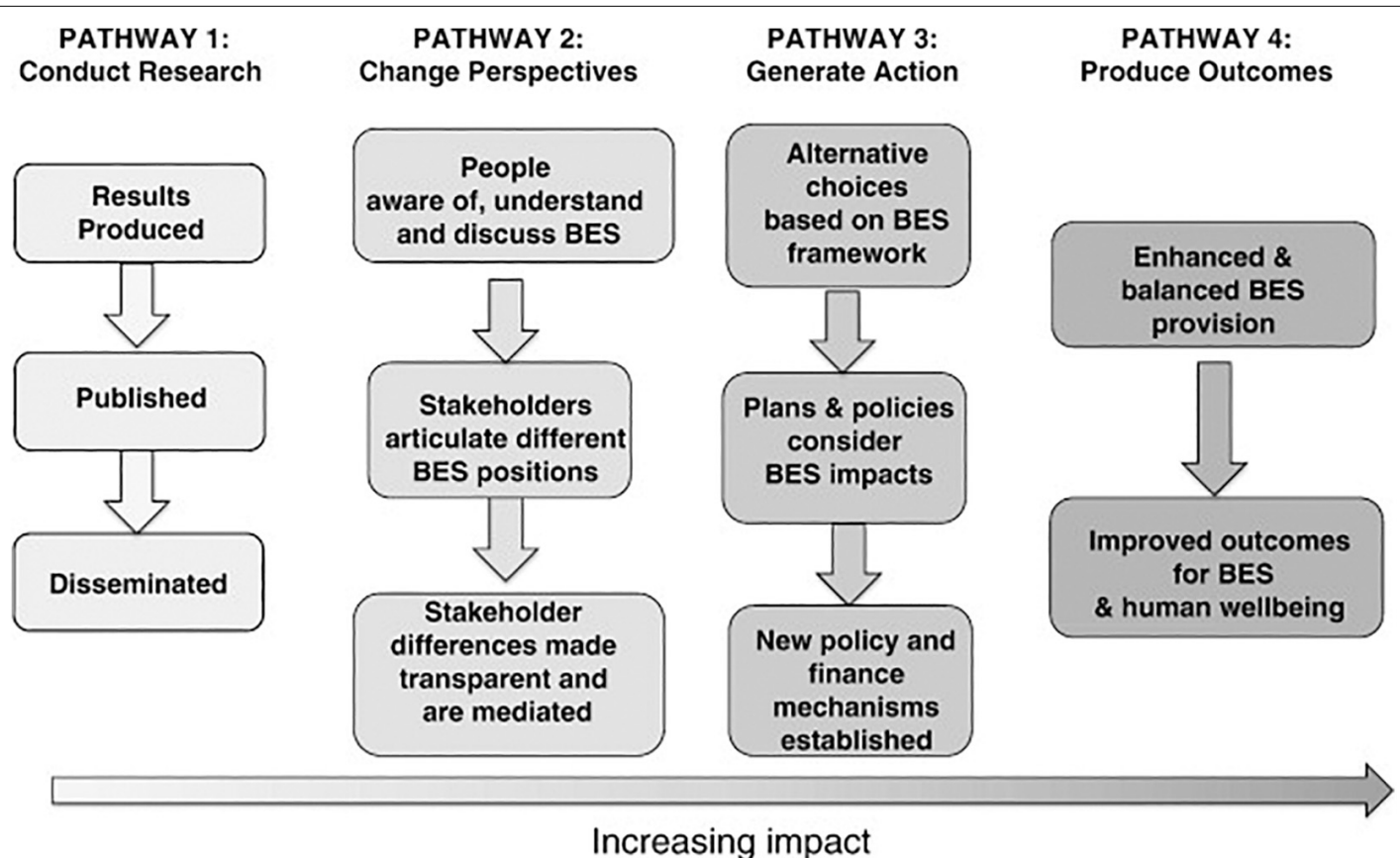

FIGURE 6 | The four pathways of impact for biodiversity and ecosystem services (BES) information on decision-making process. A pathway means a level of success achieved when science and policy act together to achieve more sustainable management of CMES. Pathway 1 represents the creation of new, high-quality and relevant information on CMES. Pathway 2 provides new understanding, thus, raising awareness or achieving mind-shift. Pathway 3 represents the influence of CMES information on specific actions and the behavior of decision-makers. Pathway 4 achieves specific outcomes in terms of developing new policy or finance mechanisms, and making measurable improvements in ES provision, biodiversity and human wellbeing. Reproduced from Ruckelshaus et al. (2015); open access under the Creative Commons Attribution-Non-commercial-No Derivatives License - CC BY NC ND). 
are clearly documented, published, and validation tests reveal limitations (Kareiva et al., 2011; Kim et al., 2012; Tallis et al., 2013; Arkema et al., 2013).

Once the ESA process has been framed into a science-policy context, the engagement and involvement of stakeholders is vital to ensure that the models used are the best possible to achieve the objectives established. According to Guerry et al. (2012), for a model to be useful in most decision context, it needs to evaluate how changes in ecosystem structure and function will affect the flow of services. In other words, by the analysis of input variation (i.e., labor, materials, habitat), models should predict the production of outputs (i.e., fish, wood, aesthetic value, coastal protection). The valuation of such changes, whether in monetary or other terms, ultimately provides the common language for decision making (Barbier et al., 2011). A tool developed to provide this is the NatCap Project's suite of models called InVEST.

The InVEST is flexible and scientifically grounded and possess six main characteristics: it derives ES flow from the underlaying biophysical processes that produce them, it is spatially explicit, outputs are not limited to monetary values, it is scenario driven, it reveals relationships among multiple ES, and it has a tiered approach to accommodate a range of data availability and knowledge of the system (Guerry et al., 2012; Arkema et al., 2013). The tiered modeling approach ensures that the models are useful in various contexts, including in places with sparse data (Daily et al., 2009). Tier 1 models, for example, have modest data requirements and can inform general planning. Tier 2 models could calculate ES levels and corresponding values, whereas Tier 3 models integrate complex models, developed in partnerships with other research institutions, which include analyses of ES change in fine temporal scales and analysis of feedbacks among different ES (Fulton et al., 2004a,b; Sanchirico and Mumby, 2009).

Although the three tiers of complexity initially planned for InVEST models seemed reasonable, their engagement in the real world has led to the development of even simpler Tier 0 models, that are especially useful in those places where stakeholders have discrepancies about which ES should receive more attention, or which management scenarios should be evaluated with priority (Guerry et al., 2012). For example, in the spatial coastal planning of the West Coast of Vancouver Island, what decision-makers needed at first was a simple screening tool to rank and highlight areas most vulnerable to coastal hazards under different scenarios of habitat presence (Arkema et al., 2013).

Initially developed for land-based ecosystems, the InVEST toolbox now includes models for marine and coastal systems for renewable energy (Tier 1), food from fisheries (Tiers 0 and 1) and aquaculture (Tier 1), coastal protection (Tiers 0 and 1 ), the provisioning of aesthetic views (Tier 0 ), recreation (Tiers 0 and 1), carbon storage and sequestration (Tier 1). Marine InVEST also includes two supporting service models that account for ecological linkages between the processes that generate changes in the ES listed above: water quality (Tiers 0 and 1 ) and habitat risk assessment (Tier 0 ).

One main advantage of InVEST is that it was explicitly designed to integrate stakeholder engagement through an iterative process that involves the identification of objectives, for which the model is needed; the development of scenarios, meaning the possible effect of management interventions on the flow of CMES; and the compilation of data necessary to run the model. Therefore, simple and transparent tools with a low entry barrier can enable stakeholders with limited data availability to actively engage in a deliberative decision-making process (Kubiszewski et al., 2017). Complexity should be an aim only when conditions of data availability and capacity allow it, while special attention should be given to the value and demand for robust, simple models to inform decisions in the ESA context (Pendleton et al., 2015; Ruckelshaus et al., 2015; Evans, 2019).

\section{Lesson 3 - Beyond Stakeholder Participation: Empowering Local Experts With Technical Tools}

The operationalization of the ESA for the management of CMES requires the involvement of a variety of stakeholders (policymakers, decision-makers, practitioners, local scientists), whom Drakou et al. (2017) called 'end-users'. However, stakeholders have usually different interests or priorities (Weichselgartner and Kasperson, 2010; Dick et al., 2018), which makes it especially challenging to successfully integrate their participation into the ESA. Therefore, a pervasive trend has unfortunately established in the science-policy interface, i.e., that policy-makers use little available research-based knowledge, and researchers produce insufficient knowledge which is directly usable for policy-makers (Posner et al., 2016; Milon and Alvarez, 2019).

To achieve a better collaboration and integration of the science-policy interface, Drakou et al. (2017) proposes five points to be considered:

(1) Balance values, power relations, attitudes, and expectations of involved stakeholders, by using collaborative decisionmaking tools like workshops, focus groups, participatory mapping, and modeling (Voinov and Bousquet, 2010; Ruiz-Frau et al., 2011; Kenter et al., 2016b; Ranger et al., 2016);

(2) Communication of the levels of confidence of scientific results, thus, favoring the build-up of trust by decisionmakers in research (Gissi et al., 2017);

(3) Convergent use of language during stakeholder participation, less discipline-specific jargon and employment of user-oriented terminology (Weichselgartner and Kasperson, 2010);

(4) Communication of challenges to funding agencies, since funding sources for interdisciplinary research are still sporadic and vary between countries, consistency in such funding should be encouraged (Bremer et al., 2015; Beaumont et al., 2017); and

(5) Persuasion of government institutions and research agencies about the need for data and information sharing (Drakou et al., 2015).

Some authors have also acknowledged the importance of carrying on the ESA at a local level (Crossman et al., 2013; Ruckelshaus et al., 2015; Beaumont et al., 2017; Lau et al., 2019), because it addresses specific management issues, hence, having the potential to generate higher impact on the decisionmaking process. This local application opens the opportunity 
to bring closer the tools of the ESA to local experts (scientists and decision-makers), like those using the InVEST platform. Ruckelshaus et al. (2015) found that in places where local partners received training in ESA tools, like in Latin America (GoldmanBenner et al., 2012), Belize (Coastal Zone Management Authority Institute [CZMAI], 2012), and China (Daily et al., 2013), an ESA spreads rapidly and CMES information is adopted in policy. The final outcome is higher buy-in and ownership of the results by stakeholders, allowing policy change to happen more broadly (Dick et al., 2018; Robinne et al., 2018).

\section{Lesson 4 - Value Does Not Always Mean Money}

Regarding the ESP, nothing has been more controversial than the issue of valuation (Farley, 2012; Parks and Gowdy, 2013; Norton and Hynes, 2014; Marre et al., 2016). Perhaps the quote from Braat and de Groot (2012):(12) can illustrate this well: "To value is to monetize in the eyes of many, some of which state this with enthusiasm, others with horror."

The rise of the ES concept in 1997 saw many scientists facing the dichotomy of accepting ES valuation as useful for policy-making (Costanza, 1998; Daly, 1998) or rejecting it for considering it useless and morally unacceptable (Norgaard and Bode, 1998; Toman, 1998). Regardless of this, few focused on arguing why valuation had to be considered a synonym of monetization (Parks and Gowdy, 2013).

Understanding the meaning of value and the subsequent act of valuation is key in this debate. Box 2 contains more information about the meaning of value in the ESP. To clarify the idea of valuation, we need to make a distinction between the process of valuation and the content of valuation. Himes and Muraca (2018) refer to the process of valuation as how it occurs that something we encounter becomes important, significant, or worth our attention; while the content of valuation is the product of the process of valuation and it refers to what is valued and how the value is attributed and articulated. Therefore, when people talk about valuation simply as monetarization, they are just seeing half of the picture (Figure 7). The use of unidimensional value framings, for example economic, social, cultural, or ecological (Figure 7, left panel), creates valuation gaps and a strong contrast, if compared with the application of a more integrated approach that aims at bridging different value dimensions (Figure 7, right panel), associated with value pluralism (Pascual et al., 2017).

Moving beyond monetary valuation has been the focus of many interesting studies (Farley, 2012; Kenter et al., 2015; Irvine et al., 2016; Kenter et al., 2016a,b; Marre et al., 2016; Mavrommati et al., 2017; Small et al., 2017) which dealt with the widespread misconception that the ESA always requires an economic valuation (Engel et al., 2008; Loomis et al., 2014; Kubiszewski et al., 2017). Issues emerging from the use of monetarization in ES valuation lie, on the one side, on the economic model itself, which has led conventional economists pursue the maximization of monetary value, by integrating ES into the market framework (Farley, 2012). Gowdy (2004, 2005) called the basic economic model a "financial investment model" which serves only individuals and purely economic decisions. On the other hand, a persistent and critical issue in this debate is the idea of cultural ecosystem services, and those services that are often quite intangible and without obvious material benefits, which nevertheless, are closely linked with our perceptions of the world and our well-being (Small et al., 2017).

Likewise, values' elicitation has recently been questioned (Kenter et al., 2015) drawing attention to the assumption that value to society is just the aggregation of individual valuations (Klamer, 2003). This is especially true when considering the new findings in behavioral psychology, neuroscience, and social anthropology, which have shown that human decision-making is also a social, and not only an individual process (Parks and Gowdy, 2013; Rose et al., 2020). Kenter et al. (2015) elaborates extensively on the social component of ES valuation, identifying this area as one of the biggest challenges to be faced by the ESF. Their work outlines a framework of shared/social values across five dimensions: value concept, provider, intention, scale, and elicitation process. Along these dimensions, seven (non-mutually exclusive) types of shared values are identified: transcendental; cultural/societal; communal; group; deliberated and otherregarding values; and value to society (Kenter et al., 2015).

Costanza and Folke (1997) described three objectives that valuation of ES should achieve: ecological sustainability (Farley, 2012); fair distribution (Barnes, 2006; Lau et al., 2020); and efficient allocation (Farley, 2012; Steger et al., 2018). Therefore, a valuation process which explicitly includes non-market values, mostly from regulating and cultural services (Arias-Arévalo et al., 2017; Steger et al., 2018), and which allows the emergence of "shared and social values" (Kenter et al., 2015), is now elaborated in many places under names such as 'integrated valuation', and 'participatory valuation', where combinations of valuation methods are used to address the full set of values (Braat et al., 2014; Jacobs et al., 2016; Kenter et al., 2016a; Villegas-Palacio et al., 2016; Small et al., 2017).

Although decision makers are familiar with economic valuation and even consider it useful, most of them never or rarely use it (Cornwall Maritime Strategy, 2012; Marre et al., 2016; Beaumont et al., 2017). Ruckelshaus et al. (2015) reported in their work that, in many cases, stakeholders explicitly refused the attachment of monetary value to key benefits they obtain from ES. On the other hand, in places like Hawaii, both monetary and non-monetary metrics are important to decision makers (Kaiser and Roumasset, 2002). Thus, an essential lesson rescued from the application of the ESA is that the possibility to calculate monetary metrics, does not necessarily imply its relevance to inform decisions (Robinne et al., 2018; Milon and Alvarez, 2019). Ruckelshaus et al. (2015) acknowledged that persistence on economic valuation only represents a barrier for both the science development side (i.e., for those who imagine their work is not relevant if they are not interested in formal monetary valuation) and the practitioner side (i.e., for those who believe that an ESA excludes the value of biodiversity for its own sake).

\section{Lesson 5 - Emphasize the Link to Human Well-Being}

The MEA (2005) concluded that although many of the ES provided by nature have experienced a significant decline, a steady gain in Human Well-Being (HWB) at the global scale was undeniable. However, ecologists have argued that 


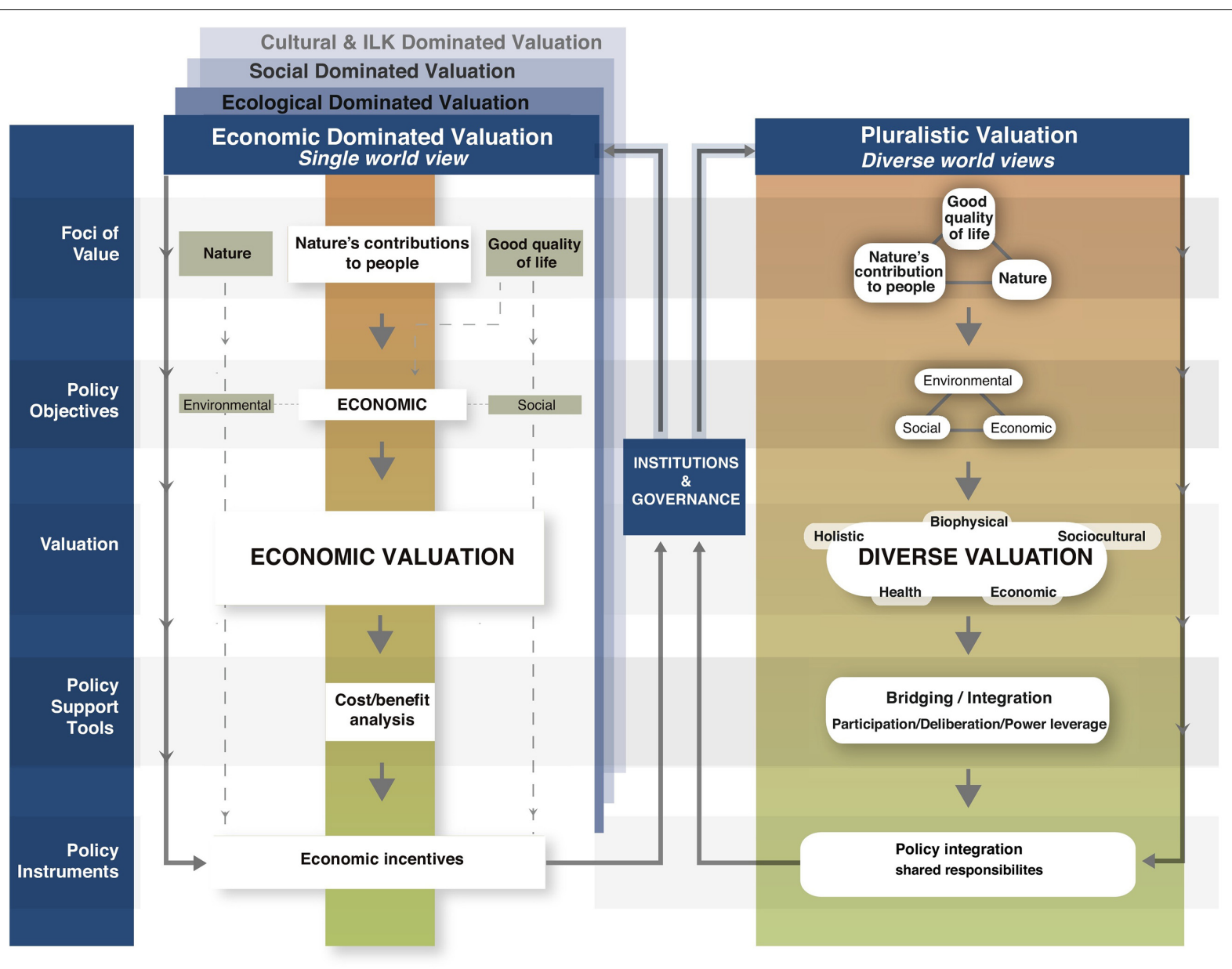

Current Opinion in Environmental Sustainability

FIGURE 7 | Comparison between two contrasting valuation approaches. The right side represents a pluralistic valuation approach, whereas the left side of the panel focuses on unidimensional valuation approach, which is linked to the long-lasting and rooted idea that valuation equals monetarization. Such misconception generates value gaps which exacerbate social injustice. Reproduced from Pascual et al. (2017); open access under the Creative Commons Attribution-Non-commercial-No Derivatives License (CC BY NC ND 4.0).

environmental degradation would be followed by a decline in the provision of ES, thus, leading to a decline in HWB (Dasgupta, 2001; Kremen, 2005; Villamagna et al., 2013). This apparent incongruency is called by Raudsepp-Hearne et al. (2010) as the 'Environmentalist's Paradox'. This paradox represents a starting point to explore the casual relationship between ES and HWB, and why, although there is overwhelming evidence of humaninduced change of biosphere through ES degradation (MEA, 2005), climate change (IPCC, 2019) and land-cover change (Kareiva et al., 2007), the consequences of those changes for human well-being are far less clear (Raudsepp-Hearne et al., 2010; Mulder et al., 2015; Rivero and Villasante, 2016).

In the ESF, a variety of definitions of $\mathrm{HWB}$ has been used (Agarwala et al., 2014), each of them using a different measure emphasis, based either on objective changes, i.e., higher income, nutrition, health (Haughton and Khandker, 2009); or subjective changes, i.e., happiness (Kahneman and Deaton, 2010) surrounding the individual. But well-being is a complex, multidimensional, dynamic concept that cannot be easily defined and measured (Fry et al., 2017); thus, hybrid approaches to HWB in the ESF should be prioritized. In this sense, the definition of HWB by Gough and McGregor (2007) as "a state of being with others, where human needs are met, where one can act meaningfully to pursue one's goals, and where one enjoys a satisfactory quality of life", is a hybridized definition which promotes a holistic approach for monitoring the impacts of interventions on people and ecosystems (Fry et al., 2017). This definition is related to the three-dimensional approach to human well-being, that includes material well-being, what people have and whether or not their needs are met; relational well-being, how social relationships enable an individual to pursue good living conditions; and subjective well-being, how individuals feel about what they have.

Although the relationships among HWB and ES are considered in a growing number of case-based research studies (Blythe et al., 2020), authors like Ruckelshaus et al. (2015); Drakou et al. (2017) and Beaumont et al. (2017) have found the link between the change in ES delivery and HWB, as one of the weakest points on many ESA experiences. Reasons for 
this weakness are various, having as main drawbacks the poor research on CMES trade-offs (Howe et al., 2014; Villasante et al., 2016); the unidimensional valuation of many CMES (Markandya et al., 2008; Naber et al., 2008); the excessive attention of research and assessment on provisioning services (Liquete et al., 2013; Grêt-Regamey et al., 2017); and the lack of exploration of the link between CMES and poverty (Daw et al., 2011; Fisher et al., 2013; Reyers et al., 2013).

In a review of the literature on trade-off and synergies when the ES concept was used to determine HWB, Howe et al. (2014) found that a major gap was the observed lack of studies within coastal and marine areas. Trade-offs occur when the provision of one ecosystem service is reduced as a consequence of increased use of another, or when more of a particular ecosystem service is captured by one stakeholder at the expense of others (Rodríguez et al., 2006). It is a particular challenge to understand the factors that influence this tradeoff dynamic, since they can occur both among stakeholders as well as among the ES being delivered in any location (Howe et al., 2014). However, this should be prioritized if we are to understand how the simultaneous uses of CMES interact, because the consequences of such interactions can be positive, e.g., ecotourism and biodiversity conservation (Mahajan and Daw, 2016; Rasheed, 2020), but in others, especially when there is resource consumption by humans, e.g., fisheries, there can be conflictive and negative (Worm et al., 2006).

As formerly elaborated in Lesson 4 (Section "Lesson 4 - Value Does Not Always Mean Money"), unidimensional valuation has led policy-making to focus attention mostly on the monetarization of ES. As a consequence, economic growth strategies, especially concerning the marine environment, have failed to acknowledge the reciprocal role that humans play both as driver of change and recipient of the impact of those changes (Daw et al., 2016; Drakou et al., 2017). At the European level though, some directives, like the Marine Strategy Framework Directive (Berg et al., 2015), have tried to shift attention toward the maintenance of a Good Ecological Status, and the assessment of coastal and marine ecosystem health (Halpern et al., 2012), shifting the attention from the purely economic aspect.

There has been a limited exploration of the link between cultural ES and well-being, if compared with the major attention received by provisioning ES (Liquete et al., 2013; Bullock et al., 2018; Wood et al., 2018). This has already been observed in the literature (Rodríguez et al., 2006; Tallis et al., 2008), and could be due to the fact that these services are not as well understood as provisioning or regulating services (Crossman et al., 2013), therefore, they are more difficult to study and measure. It could also be related to the fact that, since they are often not captured by monetary valuations, there is a general lack of interest in these types of services (Pleasant et al., 2014). Nevertheless, the relationship between ecosystems and well-being is still framed largely in terms of material benefits, i.e., harvesting fish to generate income (MEA, 2005). Although in some ESA experiences the trend is reversing, e.g., in Vancouver Island, where a key human wellbeing concern is to maintain access of First Nation communities to culturally important shellfish harvest areas (Ruckelshaus et al., 2015); or in Kenya, where ecotourism showed important cascading benefits to local people including income, as well as a stronger connection to place and opportunities to engage with outsiders (Mahajan and Daw, 2016).

Emerging from the MEA (2005), there is a new research agenda which explores how ES allocation could help on the alleviation of poverty. Links have been made between poverty and environment because poor rural people in developing countries often have higher dependence on livelihood resources directly from nature (Narayan et al., 2000). Also, because poor people are highly vulnerable to environmental change and stressors (MEA, 2005). The assessment of CMES at different spatial scales (Barbier et al., 2008) have uncovered growing inequalities within developing countries, that in some cases has led local or regional collapses, with associated forced human migration and higher resource competition (Warner et al., 2008; Daw et al., 2011). If the ESA aims to inform policy-making, a disaggregated analysis is needed that focuses on who derives which benefits from ecosystems, and how such benefits contribute to the well-being of the poor (Daw et al., 2011). This analysis should include social groupings such as gender (Fortnam et al., 2019), age and ethnicity (Cruz-Garcia et al., 2019), especially in places where inequality is greatest (Bizikova, 2012).

Fisher et al. (2013) highlighted the advantages of addressing the complexity of the Ecosystem Service - Human Well-being relation through a comprehensive approach instead of a static checklist, when using the ESA to inform decision making. In the literature, there are a variety of conceptual frameworks (e.g., Costanza et al., 2007; Bateman et al., 2011; Fisher et al., 2013; Reyers et al., 2013; Díaz et al., 2015) which, however, have focused on specification of the ecological generation of ES to the detriment of understanding how they actually contribute to well-being (Fisher et al., 2013). Perhaps the Elasticity Approach (Daw et al., 2016) represents a good approximation that seeks to incorporate multidimensional well-being (Gough and McGregor, 2007) rather than simple aggregate value as the end point. The concept of elasticity enables the capturing of important ES-HWB responses, such as non-linearity, i.e., thresholds can trigger abrupt responses in ES provisioning; hysteresis or path-dependency, i.e., highly different HWB levels according to the status of the ecosystem, either degraded or in recovery; context-dependency, i.e., availability of compensation alternatives for decline in local ES; and access-recognition (Barbier et al., 2008; Koch et al., 2009; Andersson et al., 2015; Mahajan and Daw, 2016).

\section{Lesson 6 - Communicate Uncertainties and Enhance Societal Literacy}

Based on their experience applying ESA on six cases studies across South West England and North West France, Beaumont et al. (2017) recommend to work transparently with data gaps and uncertainty. They stated that: "Decisions in marine management have to be made even if data are imperfect, missing and incomplete." Data gaps are limitations for the implementation of effective policies. However, they do not represent a barrier for the existing knowledge to generate impact 
in the policy-making process (Posner et al., 2016). Here, it is important to create a distinction between information, as a tangible, factual output of scientific research produced through specific ES analyses, and knowledge, as a body of information learned and conveyed through scientific and policy processes (Posner et al., 2016).

The impacts of the ESA-generated knowledge on policymaking will depend on the efficient collaboration, engagement, and trust between stakeholders along the process of the ESA application to ultimately generate salient, credible, and legitimate knowledge (Cash et al., 2003). The latter three characteristics are identified by Cash et al. (2003) as enabling conditions to link knowledge with action. Salience refers to the relevance of scientific knowledge to the needs of decision-makers; credibility comes from scientific and technical arguments being trustworthy and expert-based; and legitimacy refers to knowledge that is produced in the less possible unbiased way and that fairly considers stakeholders' different points of view.

In a quantitative review of 15 cases about the impacts of ESA-generated knowledge on policy-making, Posner et al. (2016) found that impact tends to increase with higher levels of salience, credibility, and legitimacy, however, legitimacy emerged as a stronger predictor of impact. This reaffirms Lesson 1 (Section "Lesson 1 - Impacts Are Greater When the ESA Is Part of a Science-Policy Process"), and indicates the importance of ES knowledge perception in the policymaking process to help shape conversations and raise awareness. Although uncertainty concerning model outputs, methods used, or knowledge gaps rising along the way, the importance of acknowledging and clearly communicating such uncertainty to end-users is vital to ensure better outcomes. In this regard, Irvin and Stansbury (2004); Reed (2008); and Beaumont et al. (2017) have found that stakeholders are used to making decisions where uncertainty is high, and responded well to the outputs despite the limitations.

Furthermore, in many cases, communication of final outcomes was restricted to end-users at workshops, which, in spite of empowering the users, limited the spread of the results to the general public as well as the decision-makers (Beaumont et al., 2017; Drakou et al., 2017). To mainstream ES and to subsequently use the ESA is another lesson. Perhaps the integration of the ESA in helping to achieve the UN Sustainable Development Goals (SDGs) will contribute to this purpose. Wood et al. (2018) found that many experts acknowledged that a variety of individual ES could make important contributions to achieving 41 targets across 12 SDGs. Although the contribution of these services to SDG14.1 (Life Bellow Water) was qualified as weak, results could be biased by expert's background and their representation in the research survey, or by focusing mostly on conservation targets (Wood et al., 2018).

Most of the reviews have also recognized the variety of informal settings in which ESA knowledge is generated, and which is not properly stored. Therefore, it is recommended that the ESA is clearly stored, with good accessibility of documentation of the methods, the results, and the implementation of the results, including mistakes made (Ruckelshaus et al., 2015; Beaumont et al., 2017). Platforms like Oppla ${ }^{4}$, Panorama $^{5}, \mathrm{SWEEP}^{6}$, and ValuES ${ }^{7}$ may provide a valuable method of storing and sharing data and experiences.

\section{CONCLUSION}

This review summarizes the current knowledge status of CMES, their emerging position into the ES concept, the development of their research agenda into the ESF, and its integration into policy and management through the ESA. The ES concept has certainly become one of the most used argumentations to protect nature (Gómez-Baggethun et al., 2010; Muradian, 2017), possibly leading to the raise of a new paradigm in conservation, an ecosystem services paradigm (Braat and de Groot, 2012). However, discrepancies around its definition (Boyd and Banzhaf, 2007; Polasky and Segerson, 2009), system classification (Fisher et al., 2009; Liquete et al., 2013), as well as with its knowledge framework (Haines-Young and Potschin, 2010; Costanza et al., 2017) are still present in the scientific community. However, practical approaches such as guided pluralism applied to the ES definition (Hermelingmeier and Nicholas, 2017) and the use of ES concept as boundary object (Nahlik et al., 2012) have facilitated the incorporation of the ES concept into the policymaking agenda globally (Daily et al., 2009; Maes et al., 2012; Börger et al., 2014).

CMES are a relatively young theme in the ESP (GómezBaggethun et al., 2010; Liquete et al., 2013) gaining mainstream attention after the MEA releasement in 2005. Nevertheless, CMES has experienced a slower knowledge build-up and underdevelopment of assessment methods, when compare to land ES (Guerry et al., 2012; Maes et al., 2012; Patterson and Glavovic, 2013; Townsend et al., 2018). Reasons for this gap are related to the inherit challenges of studying marine ecosystems (Carr et al., 2003; Townsend et al., 2018), leading to major research being done in coastal ecosystems services (Costanza et al., 2008; Chen et al., 2009; Hicks, 2011; Zhang and Smith, 2011) leaving behind other services provided by areas such as the open sea (Stocker, 2015) or the deep sea (Thurber et al., 2014). Furthermore, spatial data scarcity (Guerry et al., 2012;

${ }^{4}$ Oppla is the EU Repository of Nature-Based Solutions. It works like a repository of documented ES applications as well as a community with a great variety of people's background with the purpose of simplifying how to share, obtain and create knowledge to better manage our environment. More information available at www.oppla.eu.

${ }^{5}$ PANORAMA is a partnership initiative to document and promote examples of a range of conservation and sustainable development topics, enabling practitioners to share and reflect on their experiences, increase recognition for successful work, and to learn with their peers how similar challenges have been addressed around the globe. More information available at www.panorama.solutions/en.

${ }^{6}$ The South West Partnership for Environment and Economic Prosperity (SWEEP) is an initiative that aims helping to deliver economic and community benefits to the South West United Kingdom area. Its aim is to bring academic experts, businesses and policy makers together to solve some of the challenges involved in managing, utilizing and improving the natural environment. More information available at www.sweep.ac.uk.

${ }^{7}$ The project ValuES helps practitioners, planners, and decision-makers in government, academia. and civil society to integrate ES into planning, policy and decision-making. It has established partnerships with more than 20 countries and supports institutions such as the IPBES. More information available at www.aboutvalues.net. 
Townsend et al., 2014; Nahuelhual et al., 2020) have highly limited the elaboration of CMES delivery maps, which are significantly relevant when assessing land ES at large scales. As a consequence, most of the research on CMES has been focused at local scales (Liquete et al., 2013; Townsend et al., 2018), which might be detrimental for assessing global services such as climate regulation, in which the scale of assessment is at the level of square kilometers or larger (Bouillon et al., 2008; Lovelock, 2008).

Coastal and marine areas are dunned to great current human pressure (Small and Nicholls, 2003; Diop and Scheren, 2016), with future status having even less odds of improving if current management and business-as-usual continue (Burkhard et al., 2012; IPCC, 2019). Therefore, CMES need to be assessed, valued and gradually integrated into the decision-making process (Daily et al., 2009; Beaumont et al., 2017). The ESA has facilitated this integration, although with different levels of impact (Ruckelshaus et al., 2015) and success (Laurans et al., 2013). Nevertheless, important lessons can be rescued from worldwide ESA application experiences, serving as motors of future improvement for the approach (Richardson et al., 2015; Beaumont et al., 2017; Steger et al., 2018). This review derived six lessons: (1) integration of the ESA in a science-policy process; (2) more simplicity for the CMES prediction models; (3) move from simple participation toward empowering of stakeholders; (4) integration of the value pluralism of CMES with less focus on money; (5) the link of ES to WHB must not been forgotten; and (6) communication of results and social literacy are key. These lessons draw attention toward parts of the ESA which either need more research (Drakou et al., 2017; Blythe et al., 2020) or a change of perspective (Coastal Zone Management Authority Institute [CZMAI], 2012; Small et al., 2017; Evans, 2019), if the aim is to integrate the knowledge generated from CMES assessment to sustainably manage and preserve the coastal and marine ecosystems of the world (Mahajan and Daw, 2016; Wood et al., 2018). There is a great body of literature from which ESA can keep the momentum growth, whereby the whole society can achieve an organized, science-based, participatory, and inclusive management of CMES.

\section{TERMS AND ACRONYMS}

Ecosystem services (ES): the end products of ecosystems utilized actively or passively to produce human well-being. Ecosystem Services Framework (ESF): it is discursive tool focused in two core topics, the classification of ES, and the evaluation of the connections that those services have to human well-being. Ecosystem Services Approach (ESA): a novel management tool which gathers views from the ecosystem-based management approach and the ideas of the ESF. Ecosystem Services Paradigm (ESP): the incorporation and apparent prevalence of the ES concept into the conservation agenda. Coastal and Marine

\section{REFERENCES}

Adler, J. H. (2002). Fables of the Cuyahoga: Reconstructing a History of Environmental Protection. Faculty Publications. 191. Available online at: https:
Ecosystem Services (CMES): those services produced on the marine ecosystems (areas deeper than 50 meters), and coastal ecosystems (areas located between 50 meters below mean sea level and 50 meters above the high tide level). Ecological production function (EPF): it is the set of processes that occur in nature which enable the generation of ES. Economic demand function (EDF): it represents the connection between the ES and the benefit we humans obtained from them. Human well-being (HWB): a state of being with others, where human needs are met, where one can act meaningfully to pursue one's goals, and where one enjoys a satisfactory quality of life.

\section{AUTHOR'S NOTE}

In 2005, the Millennium Ecosystem Assessment defined ecosystem services and proposed it as a tool to preserve and manage our ecosystems. Since then, a significant progress has been made on understanding what an ecosystem service is and how it can be used to support policy-making. However, several points of discrepancies are detectable in the literature, especially when touching those services produced and delivered by coastal and marine ecosystems. Focusing particularly on CMES this review condensed relevant points of discrepancies related to the ES concept as well as the reasons proposed to explain why a knowledge gap and an underdevelopment of assessment tools is present when comparing land ES and coastal and marine ecosystem services. Touching on these topics will help researchers to direct efforts toward yet unexplored research paths or work on the limitations of the methods and/or assessments tools for CMES. Likewise, the exploration of the applicability of CMES assessment in management is focused on rescuing those valuable lessons driven out of the application of the ecosystem service approach (ESA) to manage coastal ecosystems. These lessons are expected to call stakeholders' attention toward ESA points which need to be improved, or corrected, for a more reliable ecosystem management.

\section{AUTHOR CONTRIBUTIONS}

The author confirms being the sole contributor of this work and has approved it for publication.

\section{ACKNOWLEDGMENTS}

This work was produced as part of the first International Conference for Young Marine Researchers (ICYMARE) held in Bremen, Germany, in September 2019. My recognition to the ICYMARE organization team for the help and guidance provided during the elaboration of the manuscript.

//scholarlycommons.law.case.edu/faculty_publications/191 (accessed May 19, 2020).

Agarwala, M., Atkinson, G., Fry, B. P., Homewood, K., Mourato, S., Rowcliffe, J. M., et al. (2014). Assessing the relationship between human well-being and 
ecosystem services: A review of frameworks. Conserv. Soc. 12, 437-449. doi: 10.4103/0972-4923.155592

Ainscough, J., Vries, A., De Metzger, M., Rounsevell, M., Schröter, M., Delbaere, B., et al. (2019). Navigating pluralism: understanding perceptions of the ecosystem services concept. Ecosyst. Serv. 36:100892. doi: 10.1016/j.ecoser.2019.01.004

Andersson, E., McPhearson, T., Kremer, P., Gomez-Baggethun, E., Haase, D., Tuvendal, M., et al. (2015). Scale and context dependence of ecosystem service providing units. Ecosyst. Serv. 12, 157-164. doi: 10.1016/j.ecoser.2014.08.001

Arias-Arévalo, P., Gómez-Baggethun, E., Martín-López, B., and Pérez-Rincón, M. (2018). Widening the evaluative space for ecosystem services: a taxonomy of plural values and valuation methods. Environ. Values 27, 29-53. doi: 10.3197/ 096327118 X15144698637513

Arias-Arévalo, P., Martín-López, B., and Gómez-Baggethun, E. (2017). Exploring intrinsic, instrumental, and relational values for sustainable management of social-ecological systems. Ecol. Soc. 22:43. doi: 10.5751/ES-09812-220443

Arkema, K. K., Guannel, G., Verutes, G., Wood, S. A., Guerry, A., Ruckelshaus, M., et al. (2013). Coastal habitats shield people and property from sea-level rise and storms. Nat. Clim. Chang. 3, 913-918. doi: 10.1038/nclimate1944

Arkema, K. K., Verutes, G. M., Wood, S. A., Clarke-Samuels, C., Rosado, S., Canto, M., et al. (2015). Embedding ecosystem services in coastal planning leads to better outcomes for people and nature. Proc. Natl. Acad. Sci. U.S.A. 112, 7390-7395. doi: 10.1073/pnas.1406483112

Armoškaitè, A., Purina, I., Aigars, J., Strāke, S., Pakalniete, K., Frederiksen, P., et al. (2020). Establishing the links between marine ecosystem components, functions and services: An ecosystem service assessment tool. Ocean Coast. Manag. 193:105229. doi: 10.1016/j.ocecoaman.2020.105229

Armsworth, P. R., Chan, K. M., Daily, G. C., Ehrlich, P. R., Kremen, C., Ricketts, T. H., et al. (2007). Ecosystem-service science and the way forward for conservation. Conserv. Biol. 21, 1383-1384. doi: 10.1111/j.1523-1739.2007. 00821.x

Austen, M., Andersen, P., Armstrong, C., Döring, R., Hynes, S., Levrel, H., et al. (2019). Valuing Marine Ecosystems - Taking into account the value of ecosystem benefits in the blue economy. marXiv [Preprint]. doi: 10.31230/osf.io/vy3kp

Austen, M. C., Malcolm, S. J., Frost, M., Hattam, C., Mangi, S., Stentford, G., et al. (2011). Marine. The UK National Ecosystem Assessment Technical Report, UK National Ecosystem Assessment. Cambridge: UNEP- WCMC, 459-498.

Bagstad, K. J., Semmens, D. J., Waage, S., and Winthrop, R. (2013). A comparative assessment of decision-support tools for ecosystem services quantification and valuation. Ecosyst. Serv. 5, 27-39. doi: 10.1016/j.ecoser.2013.07.004

Balmford, A., Fisher, B., Green, R. E., Naidoo, R., Strassburg, B., Turner, R. K., et al. (2011). Bringing ecosystem services into the real world: an operational framework for assessing the economic consequences of losing wild nature. Environ. Resour. Econ. 48, 161-175. doi: 10.1007/s10640-010-9413-2

Barange, M., Bahri, T., Beveridge, M. C. M., Cochrane, K. L., Funge-Smith, S., and Poulain, F. (2018). Impacts of Climate Change on Fisheries and Aquaculture: Synthesis of Current Knowledge, Adaptation and Mitigation Options. Rome: Food and Agriculture Organization of the United Nations (FAO).

Barbier, E. B. (2007). Valuing ecosystem services as productive inputs. Econ. Policy 22, 178-229. doi: 10.1111/j.1468-0327.2007.00174.x

Barbier, E. B. (2012). Progress and challenges in valuing coastal and marine ecosystem services. Rev. Environ. Econ. Policy 6, 1-19. doi: 10.1093/reep/rer017

Barbier, E. B. (2016a). The protective service of mangrove ecosystems: a review of valuation methods. MPB 109, 676-681. doi: 10.1016/j.marpolbul.2016.01.033

Barbier, E. B. (2016b). The protective value of estuarine and coastal ecosystem services in a wealth accounting framework. Environ. Resour. Econ. 64, 37-58. doi: 10.1007/s10640-015-9931-z

Barbier, E. B. (2017). Marine ecosystem services. Curr. Biol. 27, R507-R510. doi: 10.1016/j.cub.2017.03.020

Barbier, E. B., Hacker, S. D., Kennedy, C., Koch, E. W., Stier, A. C., and Silliman, B. R. (2011). The value of estuarine and coastal ecosystem services. Ecol. Monogr. 81, 169-193. doi: 10.1890/10-1510.1

Barbier, E. B., Koch, E. W., Silliman, B. R., Hacker, S. D., Wolanski, E., Primavera, J., et al. (2008). Coastal ecosystem-based management with nonlinear ecological functions and values. Science 319, 321-323. doi: 10.1126/science.115 0349

Barnes, P. (2006). Capitalism 3.0: A Guide to Reclaiming the Commons. San Francisco: Berrett-Koehler Publishers.

Barrett, S. (2003). Environment and Statecraft: the Strategy of Environmental Treaty Making. Oxford: Oxford University Press.
Bateman, I., Munro, A., Rhodes, B., Starmer, C., and Sugden, R. (1997a). A test of the theory of reference-dependent preferences. Q. J. Econ. 112, 479-505. doi: $10.1162 / 003355397555262$

Bateman, I., Munro, A., Rhodes, B., Starmer, C., and Sugden, R. (1997b). Does part-whole bias exist? An experimental investigation. Econ. J. 107, 322-332. doi: 10.1111/j.0013-0133.1997.160.x

Bateman, I. J., Mace, G. M., Fezzi, C., Atkinson, G., and Turner, K. (2011). Economic analysis for ecosystem service assessments. Environ. Resour. Econ. 48, 177-218. doi: 10.1007/s10640-010-9418-x

Baveye, P. C., Baveye, J., and Gowdy, J. (2013). Monetary valuation of ecosystem services: It matters to get the timeline right. Ecol. Econ. 95, 231-235. doi: 10.1016/j.ecolecon.2013.09.009

Beaumont, N. J., Austen, M. C., Atkins, J. P., Burdon, D., Degraer, S., and Dentinho, T. P. (2007). Identification, definition and quantification of goods and services provided by marine biodiversity: implications for the ecosystem approach. $M P B$ 54, 253-265. doi: 10.1016/j.marpolbul.2006.12.003

Beaumont, N. J., Mongruel, R., and Hooper, T. (2017). Practical application of the Ecosystem Service Approach (ESA): lessons learned and recommendations for the future. Int. J. Biodivers. Sci. Ecosyst. Serv. Manag. 13, 68-78. doi: 10.1080/ 21513732.2018.1425222

Beder, S. (2011). Environmental economics and ecological economics: the contribution of interdisciplinarity to understanding, influence and effectiveness. Environ. Conserv. 38, 140-150. doi: 10.1017/S0376892911 $00021 \mathrm{X}$

Belhabib, D., Lam, V. W. Y., and Cheung, W. W. L. (2016). Overview of West African fisheries under climate change: impacts, vulnerabilities and adaptive responses of the artisanal and industrial sectors. Mar. Policy 71, 15-28. doi: 10.1016/j.marpol.2016.05.009

Berg, T., Fürhaupter, K., Teixeira, H., Uusitalo, L., and Zampoukas, N. (2015). The marine strategy framework directive and the ecosystem-based approach - pitfalls and solutions. Mar. Pollut. Bull. 96, 18-28. doi: 10.1016/j.marpolbul. 2015.04.050

Bizikova, L. (2012). Understanding the Contribution of the Environment to Human Well-Being: A Review of Literature. Available online at: https://www.iisd.org/publications/understanding-contribution-environmenthuman-well-being-review-literature (accessed May 14, 2020).

Blythe, J., Armitage, D., Alonso, G., Campbell, D., Esteves Dias, A. C., Epstein, G., et al. (2020). Frontiers in coastal well-being and ecosystem services research: a systematic review. Ocean Coast. Manag. 185:105028. doi: 10.1016/j.ocecoaman. 2019.105028

Börger, T., Beaumont, N. J., Pendleton, L., Boyle, K. J., Cooper, P., Fletcher, S., et al. (2014). Incorporating ecosystem services in marine planning: the role of valuation. Mar. Policy 46, 161-170. doi: 10.1016/j.marpol.2014.01.019

Bouillon, S., Borges, A. V., Castañeda-Moya, E., Diele, K., Dittmar, T., Duke, N. C., et al. (2008). Mangrove production and carbon sinks: a revision of global budget estimates. Glob. Biogeochem. Cycles 22, 1-12. doi: 10.1029/2007GB003052

Boulton, A. J., Ekebom, J., and Már, G. G. (2016). Integrating ecosystem services into conservation strategies for freshwater and marine habitats: a review. Aquat. Conserv. Mar. Freshw. Ecosyst. 26, 963-985. doi: 10.1002/aqc.2703

Boyd, D. R. (2011). The Environmental Rights Revolution: a Global Study of Constitutions, Human Rights, and the Environment. Vancouver: UBC Press.

Boyd, J., and Banzhaf, S. (2007). What are ecosystem services? The need for standardized environmental accounting units. Ecol. Econ 63, 616-626. doi: 10.1016/j.ecolecon.2007.01.002

Boyd, J., and Krupnick, A. (2013). Using ecological production theory to define and select environmental commodities for nonmarket valuation. Agric. Resour. Econ. Rev. 42, 1-32. doi: 10.22004/ag.econ.148395

Braat, L. (2013). "The value of the ecosystem services concept in economic and biodiversity policy. Ecosystem Services," in Ecosystem Services: Global Issues, Local Practices, eds S. Jacobs, N. Dendoncker, and H. Keune (San Diego, CA: Elsevier Inc), 97-103.

Braat, L. C., and de Groot, R. (2012). The ecosystem services agenda: bridging the worlds of natural science and economics, conservation and development, and public and private policy. Ecosyst. Serv. 1, 4-15. doi: 10.1016/j.ecoser.2012. 07.011

Braat, L. C., Gómez-Baggethun, E., Martín-López, B., Barton, D. N., GarcíaLlorente, M., Kelemen, E., et al. (2014). Framework for Integration of Valuation Methods to Assess Ecosystem Service Policies. European Commission EU FP7 OpenNESS Project. Brussels: European Commission. 
Bremer, L. L., Delevaux, J. M. S., Leary, J. J. K., Cox, J. L., and Oleson, K. L. L. (2015). Opportunities and strategies to incorporate ecosystem services knowledge and decision support tools into planning and decision making in Hawai'i. Environ. Manag. 55, 884-899. doi: 10.1007/s00267-014-0426-4

Brink, E., Aalders, T., Ádám, D., Feller, R., Henselek, Y., Hoffmann, A., et al. (2016). Cascades of green: a review of ecosystem-based adaptation in urban areas. Glob. Environ. Chang. 36, 111-123. doi: 10.1016/j.gloenvcha.2015.11.003

Brondizio, E. S., Gatzweiler, F., Zagrafos, C., and Kumar, M. (2010). "Sociocultural context of ecosystem and biodiversity valuation," in The Economics of Ecosystems and Biodiversity (TEEB): Ecological and Economic Foundations, eds P. Sukhdev and H. Witmer (London: Earthscan Press), 150-181.

Bullock, C., Joyce, D., and Collier, M. (2018). An exploration of the relationships between cultural ecosystem services, socio-cultural values and well-being. Ecosyst. Serv. 31, 142-152. doi: 10.1016/j.ecoser.2018.02.020

Burkhard, B., De Groot, R., Costanza, R., Seppelt, R., Jørgensen, S. E., and Potschin, M. (2012). Solutions for sustaining natural capital and ecosystem services. Ecol. Indic. 21, 1-6. doi: 10.1016/j.ecolind.2012.03.008

Burns, N. (1985). Erie: the Lake That Survived. New Jersey: Rowman \& Allanheld.

Carpenter, S. R., Mooney, H. A., Agard, J., Capistrano, D., Defries, R. S., Diaz, S., et al. (2009). Science for managing ecosystem services: beyond the millennium ecosystem assessment. Proc. Natl. Acad. Sci. U.S A. 106, 1305-1312. doi: 10. 1073/pnas.0808772106

Carr, M. H., Neigel, J. E., Estes, J. A., Andelman, S., Warner, R. R., and Largier, J. L. (2003). Comparing marine and terrestrial ecosystems: implications for the design of coastal marine reserves. Ecol. Appl. 13, 90-107.

Cash, D. W., Clark, W. C., Alcock, F., Dickson, N. M., Eckley, N., Guston, D. H., et al. (2003). Knowledge systems for sustainable development. Proc. Natl. Acad. Sci. U.S A. 100, 8086-8091. doi: 10.1073/pnas. 1231332100

CBD (2000). COP5 Decision V Ecosystem Approach. Nairobi, KY: Convention on Biological Diversity.

Chamberlain, S. A., Bronstein, J. L., and Rudgers, J. A. (2014). How context dependent are species interactions? Ecol. Lett. 17, 881-890. doi: 10.1111/ele. 12279

Chambers, J. Q., Fisher, J. I., Zeng, H., Chapman, E. L., Baker, D. B., and Hurtt, G. C. (2007). Hurricane Katrina's carbon footprint on U.S. Gulf Coast forests. Science 318, 1107-1107. doi: 10.1126/science. 1148913

Chan, K. M. A., Balvanera, P., Benessaiah, K., Chapman, M., Díaz, S., GómezBaggethun, E., et al. (2016). Why protect nature? Rethinking values and the environment. Proc. Natl. Acad. Sci. U.S A. 113, 1462-1465. doi: 10.1073/pnas. 1525002113

Chan, K. M. A., and Ruckelshaus, M. (2010). Characterizing changes in marine ecosystem services. F1000 Biol. Rep. 2:54. doi: 10.3410/B2-54

Chapin, F. S., Zavaleta, E. S., Eviner, V. T., Naylor, R. L., Vitousek, P. M., Reynolds, H. L., et al. (2000). Consequences of changing biodiversity. Nature 405, 234-242. doi: $10.1038 / 35012241$

Chapman, S. (2014). A framework for monitoring social process and outcomes in environmental programs. Eval. Program Plann. 47, 45-53. doi: 10.1016/j. evalprogplan.2014.07.004

Chauvaud, S., Bouchon, C., and Maniere, R. (1998). Remote sensing techniques adapted to high resolution mapping of tropical coastal marine ecosystems (coral reefs, seagrass beds and mangrove). Int. J. Remote Sens. 19, 3625-3639. doi: 10.1080/014311698213858

Chen, L., Wang, W., Zhang, Y., and Lin, G. (2009). Recent progresses in mangrove conservation, restoration and research in China. J. Plant Ecol. 2, 45-54. doi: 10.1093/jpe/rtp009

Coastal Zone Management Authority and Institute [CZMAI] (2012). Belize Integrated Coastal Zone Management Plan. Belize: CZMAI.

Collie, J. S., Vic Adamowicz, W. L., Beck, M. W., Craig, B., Essington, T. E., Fluharty, D., et al. (2013). Marine spatial planning in practice. Estuar. Coast. Shelf Sci. 117, 1-11. doi: 10.1016/j.ecss.2012.11.010

Cooley, S. R., Kite-Powell, H. L., and Doney, S. C. (2009). Ocean acidification's potential to alter global marine ecosystem services. Oceanography 22, 172-181.

Cornwall Maritime Strategy (2012). A Future for Maritime Cornwall: The Cornwall Maritime Strategy. 2012 - 2030. August 2012. London: Cornwall Council.

Costanza, R. (1998). Special Section: forum on valuation of ecosystem services. The value of ecosystem services. Ecol. Econ. 25, 1-2.

Costanza, R. (1999). The ecological, economic, and social importance of the oceans. Ecol. Econ. 31, 199-213. doi: 10.1016/S0921-8009(99)00079-8

Costanza, R. (2008). Ecosystem services: multiple classification systems are needed. Biol. Conserv. 141, 350-352. doi: 10.1016/j.biocon.2007.12.020
Costanza, R., and Daly, H. E. (1992). Natural capital and sustainable development. Conserv. Biol. 6, 37-46. doi: 10.1046/j.1523-1739.1992.610037.x

Costanza, R., D’Arge, R., de Groot, R., Farber, S., Grasso, M., Hannon, B., et al. (1997). The value of the world's ecosystem services and natural capital. Nature 387, 253-260.

Costanza, R., de Groot, R., Braat, L., Kubiszewski, I., Fioramonti, L., Sutton, P., et al. (2017). Twenty years of ecosystem services: how far have we come and how far do we still need to go? Ecosyst. Serv. 28, 1-16. doi: 10.1016/j.ecoser.2017.09.008

Costanza, R., De Groot, R., Sutton, P., Van der Ploeg, S., Anderson, S. J., Kubiszewski, I., et al. (2014). Changes in the global value of ecosystem services. Glob. Environ. Chang. 26, 152-158. doi: 10.1016/j.gloenvcha.2014.04.002

Costanza, R., Fisher, B., Ali, S., Beer, C., Bond, L., Boumans, R., et al. (2007). Quality of life: an approach integrating opportunities, human needs, and subjective well-being. Ecol. Econ. 61, 267-276. doi: 10.1016/j.ecolecon.2006.02.023

Costanza, R., and Folke, C. (1997). "Valuing ecosystem services with efficiency, fairness and sustainability as goals," in Nature's services: Societal Dependence on Natural Ecosystems, ed. G. C. Daily (Washington, DC: Island Press), 49-70.

Costanza, R., and Kubiszewski, I. (2012). The authorship structure of "ecosystem services" as a transdisciplinary field of scholarship. Ecosyst. Serv. 1, 16-25. doi: 10.1016/j.ecoser.2012.06.002

Costanza, R., Pérez-Maqueo, O., Martinez, M. L., Sutton, P., Anderson, S. J., and Mulder, K. (2008). The value of coastal wetlands for hurricane protection. Ambio 37, 241-248.

Crossman, N. D., Burkhard, B., Nedkov, S., Willemen, L., Petz, K., Palomo, I., et al. (2013). A blueprint for mapping and modelling ecosystem services. Ecosyst. Serv. 4, 4-14. doi: 10.1016/j.ecoser.2013.02.001

Cruz-Garcia, G. S., Vanegas Cubillos, M., Torres-Vitolas, C., Harvey, C. A., Shackleton, C. M., Schreckenberg, K., et al. (2019). He says, she says: ecosystem services and gender among indigenous communities in the Colombian Amazon. Ecosyst. Serv. 37:100921. doi: 10.1016/j.ecoser.2019.100921

Culhane, F. E., Frid, C. L. J., Royo Gelabert, E., White, L., and Robinson, L. A. (2018). Linking marine ecosystems with the services they supply: what are the relevant service providing units? Ecol. Appl. 28, 1740-1751. doi: 10.1002/eap. 1779

Daily, G. C. (1997). Nature's Services: Societal Dependence on Natural Ecosystems. Washington, DC: Island Press.

Daily, G. C., Polasky, S., Goldstein, J., Kareiva, P. M., Mooney, H. A., Pejchar, L., et al. (2009). Ecosystem services in decision making: time to deliver. Front. Ecol. Environ. 7, 21-28. doi: 10.1890/080025

Daily, G. C., Zhiyun, O., Hua, Z., Shuzhuo, L., Yukuan, W., Feldman, M., et al. (2013). Securing natural capital and human well-being: innovation and impact in China. Acta Ecol. Sin. 33, 677-685. doi: 10.5846/stxb201212311906

Dale, V. H., and Beyeler, S. C. (2001). Challenges in the development and use of ecological indicators. Ecol. Indic. 1, 3-10. doi: 10.1016/S1470-160X(01)00003-6

Daly, H. E. (1998). The return of Lauderdale's paradox. Ecol. Econ. 25, 21-23. doi: 10.1016/S0921-8009(98)00008-1

Dasgupta, P. (2001). Human Well-Being and the Natural Environment. Oxford: Oxford University Press.

Davy, A. J., Bakker, J. P., and Figueroa, M. E. (2009). "Human modification of European salt marshes," in Human Impacts on Salt Marshes: a Global Perspective, eds B. R. Silliman, E. D. Grosholz, and M. D. Bertness (Berkeley, CA: University of California Press), 311-336.

Daw, T., Brown, K., Rosendo, S., and Pomeroy, R. (2011). Applying the ecosystem services concept to poverty alleviation: the need to disaggregate human wellbeing. Environ. Conserv. 38, 370-379. doi: 10.1017/S0376892911000506

Daw, T. M., Hicks, C. C., Brown, K., Chaigneau, T., Januchowski-Hartley, F. A., Cheung, W. W. L., et al. (2016). Elasticity in ecosystem services: exploring the variable relationship between ecosystems and human well-being. Ecol. Soc. 21:211. doi: 10.5751/ES-08173-210211

De Groot, R., De Fisher, B., Christie, M., Aronson, J., Braat, L., Gowdy, J., et al. (2010a). "Integrating the ecological and economic dimensions in biodiversity and ecosystem service valuation," in The Economics of Ecosystems and Biodiversity (TEEB): Ecological and Economic Foundations, eds P. Sukhdev and H. Witmer (London: Earthscan Press), 9-40.

De Groot, R. S., Alkemade, R., Braat, L., Hein, L., and Willemen, L. (2010b). Challenges in integrating the concept of ecosystem services and values in landscape planning, management and decision making. Ecol. Complex 7, 260272. doi: 10.1016/j.ecocom.2009.10.006

Denny, M. (1993). Air and Water: the Biology and Physics of Life's Media. New Jersey: Princeton University Press. 
Deutz, A., Heal, G. M., Niu, R., Swanson, E., Townshend, T., Zhu, L., et al. (2020). Financing Nature: Closing the Global Biodiversity Financing Gap. Chicago, IL: The Paulson Institute.

Díaz, S., Demissew, S., Carabias, J., Joly, C., Lonsdale, M., Ash, N., et al. (2015). The IPBES Conceptual Framework - connecting nature and people. Curr. Opin. Environ. Sustain. 14, 1-16. doi: 10.1016/j.cosust.2014.11.002

Dick, J., Turkelboom, F., Woods, H., Iniesta-Arandia, I., Primmer, E., Saarela, S. R., et al. (2018). Stakeholders' perspectives on the operationalization of the ecosystem service concept: results from 27 case studies. Ecosyst. Serv. 29, 552-565. doi: 10.1016/j.ecoser.2017.09.015

Diop, S., Scheren, P., and Machiwa, J. F. (2016). Estuaries: A Lifeline of Ecosystem Services in the Western Indian Ocean. Cham: Springer International Publishing.

Diop, S., and Scheren, P. A. (2016). Sustainable oceans and coasts: lessons learnt from Eastern and Western Africa. Estuar. Coast. Shelf Sci. 183, 327-339. doi: 10.1016/j.ecss.2016.03.032

Dobson, A., Lodge, D., Alder, J., Cumming, G. S., Keymer, J., McGlade, J., et al. (2006). Habitat loss, trophic collapse, and the decline of ecosystem services. Ecology 87, 1915-1924.

Doney, S. C., Ruckelshaus, M., Emmett Duffy, J., Barry, J. P., Chan, F., English, C. A., et al. (2012). Climate change impacts on marine ecosystems. Ann. Rev. Mar. Sci. 4, 11-37. doi: 10.1146/annurev-marine-041911-111611

Drakou, E. G., Crossman, N. D., Willemen, L., Burkhard, B., Palomo, I., Maes, J., et al. (2015). A visualization and data-sharing tool for ecosystem service maps: lessons learnt, challenges and the way forward. Ecosyst. Serv. 13, 134-140. doi: 10.1016/j.ecoser.2014.12.002

Drakou, E. G., Kermagoret, C., Liquete, C., Ruiz-Frau, A., Burkhard, K., Lillebø, A. I., et al. (2017). Marine and coastal ecosystem services on the science-policypractice nexus: challenges and opportunities from 11 European case studies. Int. J. Biodivers. Sci. Ecosyst. Serv. Manag. 13, 51-67. doi: 10.1080/21513732.2017. 1417330

Egoh, B., Drakou, E. G., Dunbar, M. B., Maes, J., and Willemen, L. (2012). Indicators for Mapping Ecosystem Services: A Review. Ispra: European Commission, Joint Research Centre.

Egoh, B., Rouget, M., Reyers, B., Knight, A. T., Cowling, R. M., van Jaarsveld, A. S., et al. (2007). Integrating ecosystem services into conservation assessments: a review. Ecol. Econ. 63, 714-721. doi: 10.1016/j.ecolecon.2007. 04.007

Engel, S., Pagiola, S., and Wunder, S. (2008). Designing payments for environmental services in theory and practice: an overview of the issues. Ecol. Econ. 65, 663-674. doi: 10.1016/j.ecolecon.2008.03.011

Evans, N. M. (2019). Ecosystem services: on idealization and understanding complexity. Ecol. Econ. 156, 427-430. doi: 10.1016/j.ecolecon.2018.10.014

Farber, S. C., Costanza, R., and Wilson, M. A. (2002). Economic and ecological concepts for valuing ecosystem services. Ecol. Econ. 41, 375-392. doi: 10.1016/ S0921-8009(02)00088-5

Farley, J. (2012). Ecosystem services: the economics debate. Ecosyst. Serv. 1, 40-49. doi: 10.1016/j.ecoser.2012.07.002

Feld, C. K., Da Silva, P. M., Sousa, J. P., De Bello, F., Bugter, R., Grandin, U., et al. (2009). Indicators of biodiversity and ecosystem services: a synthesis across ecosystems and spatial scales. Oikos 118, 1862-1871. doi: 10.1111/j.1600-0706. 2009.17860.x

Fish, R., Church, A., and Winter, M. (2016). Conceptualising cultural ecosystem services: a novel framework for research and critical engagement. Ecosyst. Serv. 21, 208-217. doi: 10.1016/j.ecoser.2016.09.002

Fisher, B., Turner, K., Zylstra, M., Brouwer, R., De Groot, R., Farber, S., et al. (2008). Ecosystem services and economic theory: integration for policy-relevant research. Ecol. Appl. 18, 2050-2067. doi: 10.1890/07-1537.1

Fisher, B., and Turner, R. (2008). Ecosystem services: classification for valuation. Biol. Conserv. 141, 1167-1169. doi: 10.1016/j.biocon.2008.02.019

Fisher, B., Turner, R. K., and Morling, P. (2009). Defining and classifying ecosystem services for decision making. Ecol. Econ. 68, 643-653. doi: 10.1016/j.ecolecon. 2008.09.014

Fisher, J. A., Patenaude, G., Meir, P., Nightingale, A. J., Rounsevell, M. D. A., Williams, M., et al. (2013). Strengthening conceptual foundations: analysing frameworks for ecosystem services and poverty alleviation research. Glob. Environ. Chang. 23, 1098-1111. doi: 10.1016/j.gloenvcha.2013.04.002

Fortnam, M., Brown, K., Chaigneau, T., Crona, B., Daw, T. M., Gonçalves, D., et al. (2019). The gendered nature of ecosystem services. Ecol. Econ. 159, 312-325. doi: 10.1016/j.ecolecon.2018.12.018
Freeman, A. M. (2003). The Measurement of Environmental and Resource Values: Theory and Methods, 2nd Edn. Washington, DC: Resources for the Future.

Freeman, P., Rosenberger, R., Sylvia, G., Heppell, S., and Harte, M. (2013). Guide for Valuing Marine Ecosystem Services to Support Nearshore Management in Oregon. Corvallis, OR: Oregon Sea Grant, 74. Report number: ORESU-H13-002.

Fry, B., Agarwala, M., Atkinson, G., Clements, T., Homewood, K., Mourato, S., et al. (2017). Monitoring local well-being in environmental interventions: a consideration of practical trade-offs. Oryx 51, 68-76. doi: 10.1017/ S003060531500112X

Fulton, E. A., Parslow, J. S., Smith, A. D. M., and Johnson, C. R. (2004a). Biogeochemical marine ecosystem models II: the effect of physiological detail on model performance. Ecol. Model. 173, 371-406. doi: 10.1016/j.ecolmodel. 2003.09.024

Fulton, E. A., Smith, A. D. M., and Johnson, C. R. (2004b). Biogeochemical marine ecosystem models I: IGBEM - a model of marine bay ecosystems. Ecol. Model. 174, 267-307. doi: 10.1016/j.ecolmodel.2003.09.027

Gaylard, S., Waycott, M., Lavery, P., and Guthrie, A. G. (2020). Review of coast and marine ecosystems in temperate australia demonstrates a wealth of ecosystem services. Front. Mar. Sci. 7:453. doi: 10.3389/fmars.2020.00453

Gillis, L. G., Belshe, E. F., and Narayan, G. R. (2017). Deforested mangroves affect the potential for carbon linkages between connected ecosystems. Estuar. Coasts 40, 1207-1213. doi: 10.1007/s12237-017-0210-9

Gissi, E., Gaglio, M., and Reho, M. (2016). Sustainable energy potential from biomass through ecosystem services trade-off analysis: the case of the Province of Rovigo (Northern Italy). Ecosyst. Serv. 18, 1-19. doi: 10.1016/j.ecoser.2016. 01.004

Gissi, E., Menegon, S., Sarretta, A., Appiotti, F., Maragno, D., Vianello, A., et al. (2017). Addressing uncertainty in modelling cumulative impacts within maritime spatial planning in the Adriatic and Ionian region. PLoS One 12:e0180501. doi: 10.1371/journal.pone.0180501

Goldman-Benner, R. L., Benitez, S., Boucher, T., Calvache, A., Daily, G., Kareiva, P., et al. (2012). Water funds and payments for ecosystem services: practice learns from theory and theory can learn from practice. Oryx 46, 55-63. doi: 10.1017/S0030605311001050

Gómez-Baggethun, E., Groot, R., De Lomas, P. L., and Montes, C. (2010). The history of ecosystem services in economic theory and practice: from early notions to markets and payment schemes. Ecol. Econ. 69, 1209-1218. doi: 10.1016/j.ecolecon.2009.11.007

Gough, I., and McGregor, J. A. (2007). Wellbeing in Developing Countries: from Theory to Research. Cambridge: Cambridge University Press.

Gowdy, J. (2005). Toward a new welfare economics for sustainability. Ecol. Econ. 53, 211-222. doi: 10.1016/j.ecolecon.2004.08.007

Gowdy, J. M. (2004). The revolution in welfare economics and its implications for environmental valuation and policy. Land Econ. 80, 239-257. doi: 10.2307/ 3654741

Grêt-Regamey, A., Sirén, E., Brunner, S. H., and Weibel, B. (2017). Review of decision support tools to operationalize the ecosystem services concept. Ecosyst. Serv. 26, 306-315. doi: 10.1016/j.ecoser.2016.10.012

Guerry, A. D., Ruckelshaus, M. H., Arkema, K. K., Bernhardt, J. R., Guannel, G., Kim, C. K., et al. (2012). Modeling benefits from nature: using ecosystem services to inform coastal and marine spatial planning. Int. J. Biodivers. Sci. Ecosyst. Serv. Manag. 8, 107-121. doi: 10.1080/21513732.2011.647835

Guisado-Pintado, E., Navas, F., and Malvárez, G. (2016). Ecosystem services and their benefits as coastal protection in highly urbanized environments. J. Coast. Res. 1, 1097-1101. doi: 10.2112/SI75-220.1

Haines-Young, R., and Potschin, M. (2018). CICES V5. 1. Guidance on the Application of the Revised Structure. Nottingham: Fabis Consulting Ltd, 53.

Haines-Young, R. H., and Potschin, M. (2010). "The links between biodiversity, ecosystem services and human well-being," in Ecosystem Ecology: A New Synthesis, eds D. Raffaelli and C. Frid (Cambridge: Cambridge University Press), 110-139.

Halpern, B. S., Longo, C., Hardy, D., McLeod, K. L., Samhouri, J. F., Katona, S. K., et al. (2012). An index to assess the health and benefits of the global ocean. Nature 488, 615-620. doi: 10.1038/nature11397

Halpern, B. S., Walbridge, S., Selkoe, K. A., Kappel, C. V., Micheli, F., D’Agrosa, C., et al. (2008). A global map of human impact on marine ecosystems. Science 319, 948-952. doi: 10.1126/science.1149345 
Hattam, C., Atkins, J. P., Beaumont, N., Börger, T., Böhnke-henrichs, A., Burdon, D., et al. (2015). Marine ecosystem services: linking indicators to their classification. Ecol. Indic. 49, 61-75. doi: 10.1016/j.ecolind.2014.09.026

Haughton, J., and Khandker, S. R. (2009). Handbook on Poverty + Inequality. Washington, DC: World Bank Publications.

Hermelingmeier, V., and Nicholas, K. A. (2017). Identifying five different perspectives on the ecosystem services concept using Q methodology. Ecol. Econ. 136, 255-265. doi: 10.1016/j.ecolecon.2017.01.006

Hicks, C. C. (2011). How do we value our reefs? Risks and tradeoffs across scales in "biomass-based" economies. Coast. Manag. 39, 358-376. doi: 10.1080/ 08920753.2011.589219

Himes, A., and Muraca, B. (2018). Relational values: the key to pluralistic valuation of ecosystem services. Curr. Opin. Environ. Sustain. 35, 1-7. doi: 10.1016/j. cosust.2018.09.005

Horton, B., Colarullo, G., Bateman, I. J., and Peres, C. A. (2003). Evaluating nonuser willingness to pay for a large-scale conservation programme in Amazonia: a UK/Italian contingent valuation study. Environ. Conserv. 30, 139-146. doi: $10.1017 /$ S0376892903000122

Howe, C., Suich, H., Vira, B., and Mace, G. M. (2014). Creating win-wins from trade-offs? Ecosystem services for human well-being: a meta-analysis of ecosystem service trade-offs and synergies in the real world. Glob. Environ. Chang. 28, 263-275. doi: 10.1016/j.gloenvcha.2014.07.005

Hummel, C., Poursanidis, D., Orenstein, D., Elliott, M., Adamescu, M. C., Cazacu, C., et al. (2019). Protected Area management: fusion and confusion with the ecosystem services approach. Sci. Total Environ. 651, 2432-2443. doi: 10.1016/ j.scitotenv.2018.10.033

IPCC (2019). "Intergovernmental Panel for climate change special report on the ocean and cryosphere in a changing climate," in Special Report on the Ocean and Cryosphere in a Changing Climate, eds H.-O. Pörtner, D. C. Roberts, V. Masson-Delmotte, P. Zhai, M. Tignor, E. Poloczanska, et al. (Geneva: IPCC).

Irvin, R. A., and Stansbury, J. (2004). Citizen participation in decision making: is it worth the effort? Public Adm. Rev. 64, 55-65. doi: 10.1111/j.1540-6210.2004. 00346.x

Irvine, K. N., Brien, L. O., Ravenscroft, N., Cooper, N., Everard, M., Fazey, I., et al. (2016). Ecosystem services and the idea of shared values. Ecosyst. Serv. 21, 184-193. doi: 10.1016/j.ecoser.2016.07.001

Jacobs, S., Dendoncker, N., Martín-lópez, B., Nicholas, D., Gomez-baggethun, E., Boeraeve, F., et al. (2016). A new valuation school: Integrating diverse values of nature in resource and land use decisions. Ecosyst. Serv. 22, 213-220. doi: 10.1016/j.ecoser.2016.11.007

Jobstvogt, N., Townsend, M., Witte, U., and Hanley, N. (2014). How can we identify and communicate the ecological value of deep-sea ecosystem services? PLoS One 9:e0100646. doi: 10.1371/journal.pone.0100646

Kahneman, D., and Deaton, A. (2010). High income improves evaluation of life but not emotional well-being. Proc. Natl. Acad. Sci. U.S.A. 107, 16489-16493. doi: 10.1073/pnas.1011492107

Kahneman, D., Ritov, I., Jacowitz, K. E., and Grant, P. (1993). Stated willingness to pay for public goods: a psychological perspective. Psychol. Sci. 4, 310-315. doi: 10.1111/j.1467-9280.1993.tb00570.x

Kaiser, B., and Roumasset, J. (2002). Valuing indirect ecosystem services: the case of tropical watersheds. Environ. Dev. Econ. 7, 701-714. doi: 10.1017/ S1355770X02000426

Kaiser, J., Reuer, M. K., Barnett, B., and Bender, M. L. (2005). Marine productivity estimates from continuous $\mathrm{O} 2 / \mathrm{Ar}$ ratio measurements by membrane inlet mass spectrometry. Geophys. Res. Lett. 32:L023459. doi: 10.1029/2005GL0 23459

Kareiva, P., and Marvier, M. (2012). What is conservation science? Bioscience 62, 962-969. doi: 10.1525/bio.2012.62.11.5

Kareiva, P., Tallis, H., Ricketts, T., Daily, G., and Polasky, S. (2011). Natural Capital: Theory and Practice of Mapping Ecosystem Services. Oxford: Oxford University Press.

Kareiva, P., Watts, S., McDonald, R., and Boucher, T. (2007). Domesticated nature: Shaping landscapes and ecosystems for human welfare. Science 316, 1866-1869. doi: $10.1126 /$ science. 1140170

Kenter, J. O., Bryce, R., Christie, M., Cooper, N., Hockley, N., Irvine, K. N., et al. (2016a). Shared values and deliberative valuation: future directions. Ecosyst. Serv. 21, 358-371. doi: 10.1016/j.ecoser.2016.10.006
Kenter, J. O., Jobstvogt, N., Watson, V., Irvine, K. N., Christie, M., and Bryce, R. (2016b). The impact of information, value-deliberation and group-based decision-making on values for ecosystem services: integrating deliberative monetary valuation and storytelling. Ecosyst. Serv. 21, 270-290. doi: 10.1016/ j.ecoser.2016.06.006

Kenter, J. O., O’Brien, L., Hockley, N., Ravenscroft, N., Fazey, I., Irvine, K. N., et al. (2015). What are shared and social values of ecosystems? Ecol. Econ. 111, 86-99. doi: 10.1016/j.ecolecon.2015.01.006

Kim, C. K., Toft, J. E., Papenfus, M., Verutes, G., Guerry, A. D., Ruckelshaus, M. H., et al. (2012). Catching the right wave: evaluating wave energy resources and potential compatibility with existing marine and coastal uses. PLoS One 7:e0047598. doi: 10.1371/journal.pone.0047598

Kingdon, J. W. (1995). Agendas, Alternatives and Public Policies. Michigan: Addison Wesley Educational Publishers.

Klamer, A. (2003). A pragmatic view on values in economics. J. Econ. Methodol. 10, 37-41. doi: 10.1080/1350178032000071075

Kloor, K. (2015). The battle for the soul of conservation science. Issues Sci. Technol. $31,74-79$.

Koch, E. W., Barbier, E. B., Silliman, B. R., Reed, D. J., Perillo, G. M. E., Hacker, S. D., et al. (2009). Non-linearity in ecosystem services: temporal and spatial variability in coastal protection. Front. Ecol. Environ. 7, 29-37. doi: 10.1890/ 080126

Koschke, L., Fürst, C., Frank, S., and Makeschin, F. (2012). A multi-criteria approach for an integrated land-cover-based assessment of ecosystem services provision to support landscape planning. Ecol. Indic. 21, 54-66. doi: 10.1016/j. ecolind.2011.12.010

Kremen, C. (2005). Managing ecosystem services: what do we need to know about their ecology? Ecol. Lett. 8, 468-479. doi: 10.1111/j.1461-0248.2005.00 751.x

Kubiszewski, I., Costanza, R., Anderson, S., and Sutton, P. (2017). The future value of ecosystem services: global scenarios and national implications. Ecosyst. Serv. 26, 289-301. doi: 10.1016/j.ecoser.2017.05.004

Lau, J. D., Cinner, J. E., Fabinyi, M., Gurney, G. G., and Hicks, C. C. (2020). Access to marine ecosystem services: examining entanglement and legitimacy in customary institutions. World Dev. 126:104730. doi: 10.1016/j.worlddev.2019. 104730

Lau, J. D., Hicks, C. C., Gurney, G. G., and Cinner, J. E. (2019). What matters to whom and why? Understanding the importance of coastal ecosystem services in developing coastal communities. Ecosyst. Serv. 35, 219-230. doi: 10.1016/j. ecoser.2018.12.012

Laurans, Y., Rankovic, A., Billé, R., Pirard, R., and Mermet, L. (2013). Use of ecosystem services economic valuation for decision making: questioning a literature blindspot. J. Environ. Manag. 119, 208-219. doi: 10.1016/j.jenvman. 2013.01.008

Leslie, H. M., and McLeod, K. L. (2007). Confronting the challenges of implementing marine ecosystem-based management. Front. Ecol. Environ. 5, 540-548. doi: 10.1890/060093

Lillebø, A. I., Somma, F., Norén, K., Gonçalves, J., Alves, M. F., Ballarini, E., et al. (2016). Assessment of marine ecosystem services indicators: experiences and lessons learned from 14 European case studies. Integr. Environ. Assess. Manag. 12, 726-734. doi: 10.1002/ieam.1782

Link, J. S., Yemane, D., Shannon, L. J., Coll, M., Shin, Y. J., Hill, L., et al. (2010). Relating marine ecosystem indicators to fishing and environmental drivers: an elucidation of contrasting responses. ICES J. Mar. Sci. 67, 787-795. doi: 10.1093/icesjms/fsp258

Liquete, C., Piroddi, C., Drakou, E. G., Gurney, L., Katsanevakis, S., Charef, A., et al. (2013). Current status and future prospects for the assessment of marine and coastal ecosystem services: a systematic review. PLoS One 8:e067737. doi: 10.1371/journal.pone.0067737

Loomis, J., Richardson, L., Kroeger, T., and Casey, F. (2014). "Valuing ecosystem services using benefit transfer: separating credible and incredible approaches," in Valuing Ecosystem Services. Methodological Issues and Case Studies, ed. K. N. Ninan (Cheltenham: Edward Elgar Publishing), 78-89.

Lopes, R., and Videira, N. (2013). Valuing marine and coastal ecosystem services: an integrated participatory framework. Ocean Coast. Manag. 84, 153-162. doi: 10.1016/j.ocecoaman.2013.08.001

López-Rodríguez, M. D., Cabello, J., Castro, H., and Rodríguez, J. (2019). Social learning for facilitating dialogue and understanding of the ecosystem services 
approach: lessons from a cross-border experience in the Alboran Marine Basin. Sustain 11, 1-23. doi: 10.3390/su11195239

Loreau, M., Naeem, S., Inchausti, P., Bengtsson, J., Grime, J. P., Hector, A., et al. (2001). Ecology: biodiversity and ecosystem functioning: current knowledge and future challenges. Science 294, 804-808. doi: 10.1126/science.1064088

Lovelock, C. E. (2008). Soil respiration and belowground carbon allocation in mangrove forests. Ecosystems 11, 342-354. doi: 10.1007/s10021-008-9125-4

Lozoya, J. P., Sardá, R., and Jiménez, J. A. (2011). A methodological framework for multi-hazard risk assessment in beaches. Environ. Sci. Policy 14, 685-696. doi: 10.1016/j.envsci.2011.05.002

Mace, G. M., Bateman, I., Albon, S., Balmford, A., Brown, C., Church, A., et al. (2011). "Conceptual framework and methodology," in UK National Ecosystem Assessment. Technical Report, eds R. Watson, S. Albon, R. Aspinall, M. Austen, B. Bardgett, I. Bateman, et al. (Cambridge: UNEP-WCMC), 11-26.

Maes, J., Egoh, B., Willemen, L., Liquete, C., Vihervaara, P., Schägner, J. P., et al. (2012). Mapping ecosystem services for policy support and decision making in the European Union. Ecosyst. Serv. 1, 31-39. doi: 10.1016/j.ecoser.2012.06.004

Maes, J., Teller, A., Erhard, M., Liquete, C., Braat, L., Berry, P., et al. (2013). An Analytical Framework for Ecosystem Assessments Under Action 5 of the EU Biodiversity Strategy to 2020. Available online at: https://ec.europa.eu/environment/nature/knowledge/ecosystem_assessment/ pdf/MAESWorkingPaper2013.pdf (accessed February 4, 2020).

Mahajan, S. L., and Daw, T. (2016). Perceptions of ecosystem services and benefits to human well-being from community-based marine protected areas in Kenya. Mar. Policy 74, 108-119. doi: 10.1016/j.marpol.2016.09.005

Markandya, A., Nunes, P. A. L. D., Brauer, I., ten Brink, P., Kuik, O., and Rayment, M. (2008). The economics of ecosystems and biodiversity - Phase 1 (Scoping) economic analysis and synthesis. Econ. Anal. 1:142.

Marre, J. B., Thébaud, O., Pascoe, S., Jennings, S., Boncoeur, J., and Coglan, L. (2016). Is economic valuation of ecosystem services useful to decision-makers? Lessons learned from Australian coastal and marine management. Jour. of Env. Manag 178, 52-62. doi: 10.1016/j.jenvman.2016.04.014

Martínez, M. L., Intralawan, A., Vázquez, G., Pérez-Maqueo, O., Sutton, P., and Landgrave, R. (2007). The coasts of our world: ecological, economic and social importance. Ecol. Econ. 63, 254-272. doi: 10.1016/j.ecolecon.2006.10.022

Martin-Ortega, J., Ferrier, R. C., and Gordon, I. J. (2015). Water Ecosystem Services: A Global Perspective. Cambridge: UNESCO Publishing.

Mavrommati, G., Borsuk, M. E., and Howarth, R. B. (2017). A novel deliberative multicriteria evaluation approach to ecosystem service valuation. Ecol. Soc. 22, 39. doi: 10.5751/ES-09105-220239

McCauley, D. J. (2006). Selling out on nature. Nature 443, 27-28. doi: 10.1038/ $443027 \mathrm{a}$

McGlashan, D. J., and Firn, J. R. (2003). Perceived socio-economic and environmental costs and benefits of ICZM in Scotland. Scottish Geogr. J. 119, 103-119. doi: 10.1080/00369220318737166

MEA (2003). Millennium Ecosystem Assessment. Ecosystems and Human WellBeing: A Framework for Assessment. Washington: Island Press.

MEA (2005). Millennium Ecosystem Assessment. Washington: Island Press.

Mendelsohn, R., and Olmstead, S. (2009). The economic valuation of environmental amenities and disamenities: methods and applications. Annu. Rev. Environ. Resour. 34, 325-347. doi: 10.1146/annurev-environ011509-135201

Milon, J. W., and Alvarez, S. (2019). The elusive quest for valuation of coastal and marine ecosystem services. Water 11, 1-19. doi: 10.3390/w11071518

Muhar, A., Raymond, C. M., Born, R. J. G., Van Den, Bauer, N., Böck, K., et al. (2017). A model integrating social-cultural concepts of nature into frameworks of interaction between social and natural systems. J. Environ. Plan. Manag. 61, 756-777. doi: 10.1080/09640568.2017.1327424

Mulder, C., Bennett, E. M., Bohan, D. A., Bonkowski, M., Carpenter, S. R., Chalmers, R., et al. (2015). 10 years later: revisiting priorities for science and society a decade after the millennium ecosystem assessment. Adv. Ecol. Res. 53, 1-53. doi: 10.1016/bs.aecr.2015.10.005

Muradian, R. (2017). "The ecosystem services paradigm: rise, scope and limits," in Rethinking Nature, ed. A. Choné (London: Routledge), 195-208.

Naber, H., Lange, G., and Hatziolos, M. (2008). Valuation of Marine Ecosystem Services: A Gap Analysis. Washington, DC: World Bank.

Nahlik, A. M., Kentula, M. E., Fennessy, M. S., and Landers, D. H. (2012). Where is the consensus? A proposed foundation for moving ecosystem service concepts into practice. Ecol. Econ. 77, 27-35. doi: 10.1016/j.ecolecon.2012.01.001
Nahuelhual, L., Vergara, X., Bozzeda, F., Campos, G., Subida, M. D., Outeiro, L., et al. (2020). Exploring gaps in mapping marine ecosystem services: a benchmark analysis. Ocean Coast. Manag. 192:105193.

Narayan, D., Chambers, R., Shah, M. K., and Petesch, P. (2000). Voices of the Poor: Crying Out for Change. New York, NY: Oxford University Press for the World Bank.

Narayan, S., Beck, M. W., Reguero, B. G., Losada, I. J., Van Wesenbeeck, B., Pontee, N., et al. (2016). The effectiveness, costs and coastal protection benefits of natural and nature-based defences. PLoS One 11:e0154735. doi: 10.1371/ journal.pone. 0154735

Needham, H. R., Pilditch, C. A., Lohrer, A. M., and Thrush, S. F. (2011). ContextSpecific bioturbation mediates changes to ecosystem functioning. Ecosystems 14, 1096-1109. doi: 10.1007/s10021-011-9468-0

Norgaard, R. B. (2010). Ecosystem services: from eye-opening metaphor to complexity blinder. Ecol. Econ. 69, 1219-1227. doi: 10.1016/j.ecolecon.2009. 11.009

Norgaard, R. B., and Bode, C. (1998). Next, the value of God, and other reactions. Ecol. Econ. 25, 37-39. doi: 10.1016/S0921-8009(98)00012-3

Norton, D., and Hynes, S. (2014). Valuing the non-market benefits arising from the implementation of the EU Marine Strategy Framework Directive. Ecosyst. Serv. 10, 84-96. doi: 10.1016/j.ecoser.2014.09.009

O'Garra, T. (2009). Bequest values for marine resources: how important for indigenous communities in less-developed economies? Environ. Resour. Econ. 44, 179-202. doi: 10.1007/s10640-009-9279-3

O’Higgins, T., Nogueira, A. A., and Lillebø, A. I. (2019). A simple spatial typology for assessment of complex coastal ecosystem services across multiple scales. Sci. Total Environ. 649, 1452-1466. doi: 10.1016/j.scitotenv.2018.08.420

Olander, L. P., Johnston, R. J., Tallis, H., Kagan, J., Maguire, L. A., Polasky, S., et al. (2018). Benefit relevant indicators: ecosystem services measures that link ecological and social outcomes. Ecol. Indic. 85, 1262-1272. doi: 10.1016/ j.ecolind.2017.12.001

Olsen, S., Tobey, J., and Kerr, M. (1997). A common framework for learning from ICM experience. Ocean Coast. Manag. 37, 155-174. doi: 10.1016/S09645691(97)90105-8

O'Neill, J. (2002). Ecology, Policy and Politics: Human Well-Being and the Natural World. London: Routledge Press.

Ostrom, E. (2009). A general framework for analyzing sustainability of socialecological systems. Science 325, 419-422. doi: 10.1126/science.1172133

Stevenson, A. (2010). Oxford Dictionary of English. Oxford: Oxford University Press.

Pagella, T. F., and Sinclair, F. L. (2014). Development and use of a typology of mapping tools to assess their fitness for supporting management of ecosystem service provision. Landsc. Ecol. 29, 383-399. doi: 10.1007/s10980-0139983-9

Parks, S., and Gowdy, J. (2013). What have economists learned about valuing nature? A review essay. Ecosyst. Serv. 3, e1-e10. doi: 10.1016/j.ecoser.2012. 12.002

Pascual, U., Balvanera, P., D1, S., Roth, E., Stenseke, M., Watson, R. T., et al. (2017). Valuing nature's contributions to people: the IPBES approach. Curr. Opin. Environ. Sustain. 26-27, 7-16. doi: 10.1016/j.cosust.2016.12.006

Patterson, M., and Glavovic, B. (2013). From frontier economics to an ecological economics of the oceans and coasts. Sustain. Sci. 8, 11-24. doi: 10.1007/s11625012-0168-2

Pearce, D. (2003). "Will global warming be controlled? reflections on the irresolution of humankind," in Challenges to the World Economy, eds R. Pethig and M. Rauscher (Heidelber: Springer-Verlag), 367-381. doi: 10.1007/978-3642-19018-6

Pearce, D. (2007). Do we really care about biodiversity? Environ. Resource Econ. 37, 313-333. doi: 10.1007/s10640-007-9118-3

Pendleton, L., Mongruel, R., Beaumont, N., Hooper, T., and Charles, M. (2015). A triage approach to improve the relevance of marine ecosystem services assessments. Mar. Ecol. Prog. Ser. 530, 183-193. doi: 10.3354/meps11111

Pendleton, L. H., Thébaud, O., Mongruel, R. C., and Levrel, H. (2016). Has the value of global marine and coastal ecosystem services changed? Mar. Policy 64, 156-158. doi: 10.1016/j.marpol.2015.11.018

Pérez-Maqueo, O., Intralawan, A., and Martínez, M. L. (2007). Coastal disasters from the perspective of ecological economics. Ecol. Econ. 63, 273-284. doi: 10.1016/j.ecolecon.2006.11.011

Pittman, S. J., Kneib, R. T., and Simenstad, C. A. (2011). Practicing coastal seascape ecology. Mar. Ecol. Prog. Ser. 427, 187-190. doi: 10.3354/meps09139 
Pleasant, M. M., Gray, S. A., Lepczyk, C., Fernandes, A., Hunter, N., and Ford, D. (2014). Managing cultural ecosystem services. Ecosyst. Serv. 8, 141-147. doi: 10.1016/j.ecoser.2014.03.006

Polasky, S., and Segerson, K. (2009). Integrating ecology and economics in the study of ecosystem services: some lessons learned. Annu. Rev. Resour. Econ. 1, 409-434. doi: 10.1146/annurev.resource.050708.144110

Posner, S. M., McKenzie, E., and Ricketts, T. H. (2016). Policy impacts of ecosystem services knowledge. Proc. Natl. Acad. Sci. U.S.A. 113, 1760-1765. doi: 10.1073/ pnas. 1502452113

Potschin, M., and Haines-Young, R. (2016). "Defining and measuring ecosystem services," in Routledge Handbook of Ecosystem Services, eds M. Potschin, R. Haines-Young, R. Fish, and R. Turner (New York, NY: Routledge), 25-44.

Potschin, M., and Haines-Young, R. (2017). "Linking people and nature: socioecological systems," in Mapping Ecosystem Services, eds B. Burkhard and J. Maes (Sofia: Pensoft Publishers), 41-43.

Potschin, M. B., and Haines-Young, R. H. (2011). Ecosystem services: exploring a geographical perspective. Prog. Phys. Geogr. 35, 575-594. doi: 10.1177/ 0309133311423172

Potschin-Young, M., Czúcz, B., Liquete, C., Maes, J., Rusch, G. M., and HainesYoung, R. (2017). Intermediate ecosystem services: an empty concept? Ecosyst. Serv. 27, 124-126. doi: 10.1016/j.ecoser.2017.09.001

Poursanidis, D., Topouzelis, K., and Chrysoulakis, N. (2018). Mapping coastal marine habitats and delineating the deep limits of the Neptune's seagrass meadows using very high-resolution Earth observation data. Int. J. Remote Sens. 39, 8670-8687. doi: 10.1080/01431161.2018.1490974

Raffaelli, D., and White, P. C. L. (2013). Ecosystems and Their Services in a Changing World. An Ecological Perspective, 1st Edn, Amsterdam: Elsevier Ltd, doi: 10.1016/B978-0-12-417199-2.00001-X

Ranger, S., Kenter, J. O., Bryce, R., Cumming, G., Dapling, T., Lawes, E., et al. (2016). Forming shared values in conservation management: an interpretivedeliberative-democratic approach to including community voices. Ecosyst. Serv. 21, 344-357. doi: 10.1016/j.ecoser.2016.09.016

Rasheed, A. R. (2020). Marine protected areas and human well-being - A systematic review and recommendations. Ecosyst. Serv. 41:101048. doi: 10.1016/j.ecoser. 2019.101048

Raudsepp-Hearne, C., Peterson, G. D., Teng, M., Bennett, E. M., Holland, T., Benessaiah, K., et al. (2010). Untangling the environmentalist's paradox: why is human well-being increasing as ecosystem services degrade? Bioscience 60, 576-589. doi: 10.1525/bio.2010.60.8.4

Reed, M. S. (2008). Stakeholder participation for environmental management: a literature review. Biol. Conserv. 141, 2417-2431. doi: 10.1016/j.biocon.2008. 07.014

Reyers, B. (2013). Charting the course for ecosystem service science. J. Integr. Environ. Sci. 10, 141-143. doi: 10.1080/1943815x.2012.729016

Reyers, B., Biggs, R., Cumming, G. S., Elmqvist, T., Hejnowicz, A. P., and Polasky, S. (2013). Getting the measure of ecosystem services: a social-ecological approach. Front. Ecol. Environ. 11, 268-273. doi: 10.1890/120144

Richardson, L., Loomis, J., Kroeger, T., and Casey, F. (2015). The role of benefit transfer in ecosystem service valuation. Ecol. Econ. 115, 51-58. doi: 10.1016/j. ecolecon.2014.02.018

Rivero, S., and Villasante, S. (2016). What are the research priorities for marine ecosystem services? Mar. Policy 66, 104-113. doi: 10.1016/j.marpol.2016.01.020

Robinne, F.-N., Schlaepfer, M., Gallagher, L., and Bréthaut, C. (2018). GlobalDES - A preliminary evaluation of the global mainstreaming of ecosystem services into policy. OSF [Preprint]. doi: 10.31219/osf.io/4urbd

Rockström, J. (2015). Big World, Small Planet: Abundance Within Planetary Boundaries. New Haven: Yale University Press.

Rockström, J., Sachs, J. D., Öhman, M. C., and Schmidt-Traub, G. (2013). Sustainable Development and Planetary Boundaries. Submitted to the High-Level Panel on the Post-2015 Development Agenda. Available online at: https://www. jstor.org/stable/pdf/resrep16114.pdf (accessed September 2, 2020).

Rodríguez, J. P., Beard, T. D., Bennett, E. M., Cumming, G. S., Cork, S. J., Agard, J., et al. (2006). Trade-offs across space, time, and ecosystem services. Ecol. Soc. 11:28. doi: 10.5751/ES-01667-110128

Roosevelt, T. R. (1907). Address to the Deep Waterway Convention. Memphis, TN. October, 4, 1907. Available online at: https://hdl.handle.net/2027/chi.086563523 (accessed September 5, 2020).

Rose, D. C., Mukherjee, N., Simmons, B. I., Tew, E. R., Robertson, R. J., Vadrot, A. B. M., et al. (2020). Policy windows for the environment: tips for improving the uptake of scientific knowledge. Environ. Sci. Policy 113, 47-54. doi: 10.1016/ j.envsci.2017.07.013

Rounsevell, M. D. A., Dawson, T. P., and Harrison, P. A. (2010). A conceptual framework to assess the effects of environmental change on ecosystem services. Biodivers. Conserv. 19, 2823-2842. doi: 10.1007/s10531-010-9838-5

Ruckelshaus, M., McKenzie, E., Tallis, H., Guerry, A., Daily, G., Kareiva, P., et al. (2015). Notes from the field: lessons learned from using ecosystem service approaches to inform real-world decisions. Ecol. Econ. 115, 11-21. doi: 10.1016/ j.ecolecon.2013.07.009

Ruiz-Frau, A., Edwards-Jones, G., and Kaiser, M. J. (2011). Mapping stakeholder values for coastal zone management. Mar. Ecol. Prog. Ser. 434, 239-249. doi: 10.3354/meps09136

Saarikoski, H., Jax, K., Harrison, P. A., Primmer, E., Barton, D. N., Mononen, L., et al. (2015). Exploring operational ecosystem service definitions: the case of boreal forests. Ecosyst. Serv. 14, 144-157. doi: 10.1016/j.ecoser.2015. 03.006

Sagebiel, J., Schwartz, C., Rhozyel, M., Rajmis, S., and Hirschfeld, J. (2016). Economic valuation of Baltic marine ecosystem services: blind spots and limited consistency. ICES J. Mar. Sci. 73, 991-1003. doi: 10.1093/icesjms/fsv 264

Sanchirico, J. N., and Mumby, P. (2009). Mapping ecosystem functions to the valuation of ecosystem services: implications of species - habitat associations for coastal land-use decisions. Theoret. Ecol. 2, 67-77. doi: 10.1007/s12080-0080034-0

Sandilyan, S., and Kathiresan, K. (2012). Mangrove conservation: a global perspective. Biodivers. Conserv. 21, 3523-3542. doi: 10.1007/s10531-0120388-x

Sattler, C., Loft, L., Mann, C., and Meyer, C. (2018). Methods in ecosystem services governance analysis: An introduction. Ecosyst. Serv. 34, 155-168. doi: 10.1016/ j.ecoser.2018.11.007

SCEP (1970). Man's Impact on the Global Environment: Assessment and Recommendations for Action. Cambridge: Massachusetts Institute of Technology Press.

Schaafsma, M., and Turner, R. K. (2015). "Valuation of coastal and marine ecosystem services: a literature review," in Coastal Zones Ecosystem Services. From Science to Values and Decision Making, ed. R. K. Turner (Cham: Springer International Publishing), 103-125.

Schuhmann, P. W., and Mahon, R. (2014). The valuation of marine ecosystem goods and services in the Caribbean: a literature review and framework for future valuation efforts. Ecosyst. Serv. 11, 56-66. doi: 10.1016/j.ecoser.2014. 07.013

SEEA (2020). System of Environmental-Economic Accounting 2012 - Experimental Ecosystem Accounting Revision Chapter Draft prepared Global Consultation Chapter 6: Ecosystem services concepts for accounting. Woodlawn: SEEA.

Sigman, D. M., and Hain, M. P. (2012). The biological productivity of the ocean. Nat. Educ. Knowl. 3, 1-16.

Simpson, R. D. (2016). Putting a price on. Issues Sci. Technol. 32, 57-62.

Small, C., and Nicholls, R. J. (2003). A global analysis of human settlement in coastal zones. J. Coast. Res. 19, 584-599. Available online at: https://www.jstor. org/stable/4299200

Small, N., Munday, M., and Durance, I. (2017). The challenge of valuing ecosystem services that have no material benefits. Glob. Environ. Chang. 44, 57-67. doi: 10.1016/j.gloenvcha.2017.03.005

Söderqvist, T., Eggert, H., Olsson, B., and Soutukorva, ^ (2005). Economic valuation for sustainable development in the Swedish coastal zone. Ambio 34, 169-175. doi: 10.1579/0044-7447-34.2.169

Soulé, M. E. (1985). What is conservation biology? Bioscience 35, 727-734. doi: $10.2307 / 1310054$

Spangenberg, J. H., Görg, C., Truong, D. T., Tekken, V., Bustamante, J. V., and Settele, J. (2014a). Provision of ecosystem services is determined by human agency, not ecosystem functions. Four case studies. Int. J. Biodivers. Sci. Ecosyst. Serv. Manag. 10, 40-53. doi: 10.1080/21513732.2014.884166

Spangenberg, J. H., von Haaren, C., and Settele, J. (2014b). The ecosystem service cascade: further developing the metaphor. Integrating societal processes to accommodate social processes and planning, and the case of bioenergy. Ecol. Econ. 104, 22-32. doi: 10.1016/j.ecolecon.2014.04.025

Steffen, W., Richardson, K., Rockström, J., Cornell, S. E., Fetzer, I., Bennett, E. M., et al. (2015). Planetary boundaries: guiding human development on a changing planet. Science 347, 736-747. doi: 10.1126/science.1259855 
Steger, C., Hirsch, S., Evers, C., Branoff, B., Petrova, M., Nielsen-pincus, M., et al. (2018). Ecosystem services as boundary objects for transdisciplinary collaboration. Ecol. Econ. 143, 153-160. doi: 10.1016/j.ecolecon.2017.07.016

Stocker, T. F. (2015). The silent services of the world ocean. Science 350, 764-765. doi: $10.1126 /$ science.aac8720

Tallis, H., Kareiva, P., Marvier, M., and Chang, A. (2008). An ecosystem services framework to support both practical conservation and economic development. Proc. Natl. Acad. Sci. U.S.A. 105, 9457-9464. doi: 10.1073/pnas.0705797105

Tallis, H., Lubchenco, J., and Coll, M. (2014). A call for inclusive conservation: petition for an end to the infighting that is stalling progress in protecting the planet. Nature 515, 27-28.

Tallis, H. T., Ricketts, T., Guerry, A. D., Wood, S. A., Sharp, R., Nelson, E., et al. (2013). InVEST 2.5. 3 User's Guide. The Natural Capital Projects. Stanford, CA: Stanford University.

Tarantola, A. (2005). Inverse Problem Theory and Methods for Model Parameter Estimation. Paris: Society for Industrial and Applied Mathematics.

Tarantola, A. (2006). Popper, Bayes and the inverse problem. Nat. Phys. 2, 492-494. doi: $10.1038 /$ nphys 375

TEEB (2010). The Economics of Ecosystems and Biodiversity. Ecological and Economic Foundations. London: Earthscan Press.

TEEB (2012). Why Value the Oceans - A Discussion Paper. Geneva: The Economics of Ecosystems and Biodiversity.

Teixeira, H., Lillebø, A. I., Culhane, F., Robinson, L., Trauner, D., Borgwardt, F., et al. (2019). Linking biodiversity to ecosystem services supply: patterns across aquatic ecosystems. Sci. Total Environ. 657, 517-534. doi: 10.1016/j.scitotenv. 2018.11.440

Thompson, S. C. G., and Barton, M. A. (1994). Ecocentric and anthropocentric attitudes toward the environment. J. Environ. Psychol. 14, 149-157. doi: 10. 1016/S0272-4944(05)80168-9

Thurber, A. R., Sweetman, A. K., Narayanaswamy, B. E., Jones, D. O. B., Ingels, J., and Hansman, R. L. (2014). Ecosystem function and services provided by the deep sea. Biogeosciences 11, 3941-3963. doi: 10.5194/bg-11-3941-2014

Tolvanen, H., Rönkä, M., Vihervaara, P., Kamppinen, M., Arzel, C., Aarras, N., et al. (2016). Spatial information in ecosystem service assessment: data applicability in the cascade model context. J. Land Use Sci. 11, 350-367. doi: 10.1080/1747423X.2014.947642

Toman, M. (1998). Why not to calculate the value of the world' s ecosystem services and natural capital. Ecol. Econ. 25, 57-60.

Torres, C., and Hanley, N. (2017). Communicating research on the economic valuation of coastal and marine ecosystem services. Mar. Policy 75, 99-107. doi: 10.1016/j.marpol.2016.10.017

Townsend, M., Davies, K., Hanley, N., Hewitt, J. E., Lundquist, C. J., and Lohrer, A. M. (2018). The challenge of implementing the marine ecosystem service concept. Front. Mar. Sci. 5:359. doi: 10.3389/fmars.2018.00359

Townsend, M., Thrush, S. F., Lohrer, A. M., Hewitt, J. E., Lundquist, C. J., Carbines, M., et al. (2014). Overcoming the challenges of data scarcity in mapping marine ecosystem service potential. Ecosyst. Serv. 8, 44-55. doi: 10.1016/j.ecoser.2014. 02.002

U.S. Environmental Protection Agency [U.S. EPA] (2009). Valuing the Protection of Ecological Systems And Services. A Report of the EPA Science Advisory Board. Washington, DC: EPA.

UNEP (2014). Conceptual framework for the Intergovernmental Science-Policy Platform on Biodiversity and Ecosystem Services. Decision IPBES-2/4. Report of the second session of the Plenary of the Intergovernmental Science-Policy Platform on Biodiversity and Ecosystem Services. Available online at: https: //ipbes.net/sites/default/files/downloads/Decision\%20IPBES_2_4.pdf (accessed May 22, 2020).

UNEP-WCMC (2011). Developing Ecosystem Service Indicators: Experiences and Lessons Learned from Sub-Global Assessments and Other Initiatives. Montréal: Secretariat of the Convention on Biological Diversity.

Valiela, I., Bowen, J. L., and York, J. K. (2001). Mangrove forests: One of the world's threatened major tropical environments. Bioscience 51, 807-815.

Van den Belt, M., and Cole, A. (2014). Ecosystem Goods and Services in Marine Protected Areas (MPAs). Science for Conservation 326. Wellington: Department of Conservation, 96.

Van Der Meulen, F., Bakker, T. W. M., and Houston, J. A. (2008). "The costs of our coasts: examples of dynamic dune management from Western Europe," in
Coastal Dunes, eds M. L. Martínez and N. P. Psuty (Berlin: Springer), 259-277. doi: 10.1007/978-3-540-74002-5

Van Oudenhoven, A. P. E., Petz, K., Alkemade, R., Hein, L., and De Groot, R. S. (2012). Framework for systematic indicator selection to assess effects of land management on ecosystem services. Ecol. Indic. 21, 110-122. doi: 10.1016/j. ecolind.2012.01.012

Villamagna, A. M., Angermeier, P. L., and Bennett, E. M. (2013). Capacity, pressure, demand, and flow: a conceptual framework for analyzing ecosystem service provision and delivery. Ecol. Complex 15, 114-121. doi: 10.1016/j.ecocom.2013. 07.004

Villasante, S., Lopes, P. F. M., and Coll, M. (2016). The role of marine ecosystem services for human well-being: disentangling synergies and trade-offs at multiple scales. Ecosyst. Serv. 17, 1-4. doi: 10.1016/j.ecoser.2015.10.022

Villegas-Palacio, C., Berrouet, L., López, C., Ruiz, A., and Upegui, A. (2016). Lessons from the integrated valuation of ecosystem services in a developing country: three case studies on ecological, socio-cultural and economic valuation. Ecosyst. Serv. 22, 297-308. doi: 10.1016/j.ecoser.2016.10.017

Visbeck, M. (2018). Ocean science research is key for a sustainable future. Nat. Commun. 9, 1-4. doi: 10.1038/s41467-018-03158-3

Voinov, A., and Bousquet, F. (2010). Modelling with stakeholders. Environ. Model. Softw. 25, 1268-1281. doi: 10.1016/j.envsoft.2010.03.007

Wam, H., Bunnefeld, N., Clarke, N., and Hofstad, O. (2016). Conflicting interests of ecosystem services: multi-criteria modelling and indirect evaluation of tradeoffs between monetary and non-monetary measures. Ecos. Serv. 22, 280-288. doi: 10.1016/j.ecoser.2016.10.003

Warner, K., Afifi, T., Dun, O., Stal, M., Schmidl, S., and Bogardi, J. (2008). "Human security, climate change and environmentally induced migration," in Climate Change: Addressing the Impact on Human Security in Africa and the middle east, eds M. Behnassi and K. McGlade (Athens: Hellenic Foundation for European and Foreign Policy).

Weichselgartner, J., and Kasperson, R. (2010). Barriers in the science-policypractice interface: toward a knowledge-action-system in global environmental change research. Glob. Environ. Chang. 20, 266-277. doi: 10.1016/j.gloenvcha. 2009.11 .006

Wells, P. G. (2017). The iconic Torrey Canyon oil spill of 1967 - Marking its legacy. Mar. Pollut. Bull. 115, 1-2. doi: 10.1016/j.marpolbul.2016.12.013

WFD (2000). Directive 2000/60/EC of The European Parliament and of The Council of 23 October 2000, establishing a framework for Community action in the field of water policy. J. Ref. OJL 327, 1-93.

Wood, S. L. R., Jones, S. K., Johnson, J. A., Brauman, K. A., Chaplin-Kramer, R., Fremier, A., et al. (2018). Distilling the role of ecosystem services in the sustainable development goals. Ecosyst. Serv. 29, 70-82. doi: 10.1016/j.ecoser. 2017.10.010

Woodward, R. T., and Wui, Y. S. (2001). The economic value of wetland services: a meta-analysis. Ecol. Econ. 37, 257-270. doi: 10.1016/S0921-8009(00)00276-7

Worm, B., Barbier, E. B., Beaumont, N., Duffy, J. E., Folke, C., Halpern, B. S., et al. (2006). Impacts of biodiversity loss on ocean ecosystem services. Science 314, 787-790. doi: 10.1126/science.1132294

Worm, B., Hilborn, R., Baum, J. K., Branch, T. A., Collie, J. S., Costello, C., et al. (2009). Rebuilding global fisheries. Science 325, 578-585. doi: 10.1126/science. 1173146

Yeo, B. H. (2002). "Valuing a marine park in Malaysia," in Valuing the Environment in Developing Countries: Case Studies, eds D. Pearce, C. Pearce, and C. Palmer (Cheltenham: Edward Elgar Publishing), 311-328.

Zhang, J., and Smith, M. D. (2011). Estimation of a generalized fishery model: a two-stage approach. Rev.Econ. Stat.93, 690-699.doi: 10.1162/REST_a_00075

Conflict of Interest: The author declares that the research was conducted in the absence of any commercial or financial relationships that could be construed as a potential conflict of interest.

Copyright (C) 2021 Carrasco De La Cruz. This is an open-access article distributed under the terms of the Creative Commons Attribution License (CC BY). The use, distribution or reproduction in other forums is permitted, provided the original author(s) and the copyright owner(s) are credited and that the original publication in this journal is cited, in accordance with accepted academic practice. No use, distribution or reproduction is permitted which does not comply with these terms. 